\title{
Las Clases Sociales en el Perú
}

\author{
Por el Dr. JOSE LUIS BUSTAMANTE Y RIVERO
}

\section{NOTAS PRELIMINARES}

\section{I.-Ubicación del problema dentro de los fines de la Semana Social.}

De acuerdo con las directivas trazadas por el Episcopado Nacional en su Pastoral del penúltimo enero, el fin que se propone esta Semana es poner $\alpha$ los católicos peruanos frente a frente de la realidad social del país y señalarles algunas de las tareas de mayor urgencia para modificar esa realidad en un sentido más fraternalmente humano y más auténticamente cristiano, tanto en el orden de las relaciones de trabajo como en el campo de la promoción cultural.

Para cumplir este objetivo es menester empezar por conocer esa realidad social nuestra, esto es, la posición en el actual momento de los grupos humanos que conviven en el Perú, ligados por una cierta unidad de conceptos y por ciertos mecanismos de cohesión con miras a alcanzar un estado de común bienestar material y espiritual. Esto nos lleva, en nuestro caso, a estudiar la estructura de la sociedad en que vivimos, $\alpha$ analizarla en sus elementos componentes, a descubrir las fuerzas que presiden la mútua trabazón de sus partes y a averiguar si en ella existen vicios de contextura o factores de disociación.

Sacado a la luz este panorama básico y propiamente expositivo, será más fácil incidir en el estudio cómo esa sociedad se desenvuelve en su función dinámica de organismo consciente y libre, ora en las actividades del trabajo organizado, ora en los procesos educativos y culturales; y seró también mós factible preconizar orientaciones que susciten una reforma valedera, sea de las instituciones mismas de la sociedad, sea de las actitudes reciprocas de sus componentes.

Por eso, el estudio del problema de las clases sociales en el Perú repre. senta un ineludible paso previo en las labores de la Semana y una fuente de inferencias en las que habrán de sustentarse muchas de las conclusiones de los ulteriores temas previstos. La responabilidad que esto implica, severisima por cierto, gravita pesadamente sobre los autores de esta ponencia al formular su exposición. 


\section{II.-Criterio adoptado para el enfoque del problema.}

Estamos en presencia de un asunto concreto, con existencia tangible en el mundo exterior: investigación de la realidad social de un país dado, en un momento dado. Debemos, por lo mismo, abordarlo con criterio objotivo, antes que filosófico o teórico. Damos por conocidas la doctrina y las enseñanzas de las Encíclicas Papales, así como el desarrollo que de ellas han hecho los apologistas católicos sobre las clases sociales: $\mathbf{y}$ suponemos igualmente enterados a los participantes de la Semana del meollo y tendencias de otras escuelas heterodoxas de la sociología a este respecto. Todo ello será el acervo remoto de indole intelectual que habrá de servirnos luego para enjuiciar el fenómeno de nuestras estructuras sociales y deslindar Jo que haya en él de conforme o de alejado del mensaje de Cristo. Pero en este punto inicial de nuestra labor buscamos fundamentalmente una experiencia: la versión real de algo que tenemos delante. Debe, pues, ser el nuestro un método pragmático, una actitud de observación.

Atributo inseparable de toda realidad humana es el de su mutabilidad en el tiempo. El ímpetu vital del hombre y las cambiantes condiciones. de su existencia hacen siempre diferente el hoy del ayer en la vida de las sociedades. Cada día trae consigo nuevas formas de convivencia. Por eso, si queremos afrontar con eficiencia una reforma social, deberemos informarnos de los datos que ofrezca la realidad presente. De lo contrario, correríamos el riesgo de dar como vigentes situaciones o características sociales ya históricamente superadas o caducas y de llegar a soluciones erradas - anacrónicas. Nuestra observación, por ende, antes que histórica debe ser actual.

\section{III.-Mustración preliminar sobre la nueva fisonomía del fenómeno de clases.}

Pero el hecho de que adoptemos un método pragmático y un criterio "actualista" de investigación no significa en modo alguno que hayamos de prescindir por entero de la sociología teórica o especulativa ni que volvamos las espaldas a la historia al buscar las raices del presente. Queremos, precisamente, en un esquema preliminar, bosquejar las recientes conclusiones a que llega la ciencia sociológica en punto a la evolución de las clases sociales durante el último siglo; porque se trata de nociones que no han penetrado aún $\alpha$ fondo en nuestro ambiente y cuyo desconocimiento origina un retraso en nuestra concepción de los fenómenos sociales y en la manera de orientar la solución de los diferendos entre las clases.

Hasta fines del siglo XVII, los elementos componentes de la comunidad social se agrupaban en estamentos o sectores sociales inmóviles y estables, sin penetrabilidad recíproca y fundados en conceptos de sangre o carisma hereditario (nobleza), de función religiosa (clero), de destino servil o servidumbre natural (pueblo), etc. Dentro de esta concepción las "clases" propiamente dichas no existían aún, porque el juego de los valores económicos carecía de importancia $\mathrm{y}$ de movilidad, ya que, en rigor, el derecho 
de propiedad quedaba prácticamente circunscrito a los estamentos privilegiados, erigidos bajo una u otra forma, en dispensadores del peculio popular. Junto a los estamentos florecían las castas. inspiradas en factores irrevocables de raza o linaje y de religión, que prestan a esta forma de agrupación. su doble sello característico de hermetismo y de fatalismo: la casta es cerrada e irrenunciable como la herencia; $\mathrm{y}$ es admitida sin protesta, con resignación y aún con gozo, porque trasunta un designio divino.

Dos causas fundamentales han hecho variar este panorama social en la época contemporánea, a saber: los progresos de la técnica industrigl y la creciente validez del concepto de la persona humana en la esfera de los valores dei mundo del trabajo. La revolución francesa y la revolución industrial del maquinismo son los jalones iniciales de esta transformación.

En el curso del siglo XIX, el problema económico irrumpió al exterior y se hizo cada vez más patente en la realidad social. La aparición de la fábrica y la generalización del asalariado dividieron la sociedad en dos partes: el mundo del trabajo y el mundo del capital, con un clamoroso nivel de inferioridad respecto del primero de ellos, debido principalmente a la boga de la tesis económica del "laisser faire", que permitía mantener en sus posiciones a los tenedores de la riqueza. La ubicación de cada uno de esos mundos respecto a los medios de producción determinó, según la doctrina marxista, la concepción de las dos clases antagónicas: capitalismo y proletariado. O se poseía los medios de producción. o se dependía do ellos hasta un punto de esclavitud. La consecuencia de esta desigualdad esencial de posiciones era la lucha de clases. Marx la preconizaba como una etapa obligada del proceso materialista de la historia. Frente a este enunciado rígido, la voz del Pontificado, condenando la triste condición del trabajador, comenzó a predicar a los hombres de todas las clases la justicia social cristiana.

Después, ya en nuestro siglo, el progreso industrial ha experimentado un asombroso desarrollo merced al constante crecimiento del capital y a los nuevos recursos de la técnica. Tras la pequeña industria, han surgido las grandes plantas industriales de transformación de materias primas y de aprovechamiento de energía. La física y la química están en estos momentos operando una segunda revolución industrial cuyos alcances -ejemplificados en la fuerza nuclear y en la "automación" - no es aún fácil columbrar. Todo ello ha traído consigo la necesidad de la especialización profesional en el mundo del trabajo y una especie de vuelco en la organización de la empresa. Al obrero especializado se le cotiza más alto y su nivel económico mejora cada día. La función del trabajador, antes puramente manual, se transporta gradualmente al campo intelectual. La civilización, al multiplicar las necesidades y los consumos, ha creado una multitud de nuevas líneas de negocio y empleo. El acicate de estos hechos trae a los obreros comunes hacia una mejor preparación especializada. El manejo y control de la empresa se trasladan, en rigor " de los propietarios a los técnicos, quienes realmente la dirigen y adquieren en cierto modo la calidad de copartícipes en los medios de producción. Los complicados mecanismos del equipo industrial exijen como condición de su eficacia un espíritu de solidaria colaboración 
racional y técnica que no se compagina con la separación rencorosa de las clases que intervienen en la faena productiva. Nuevas figuras jurídicas como la elevación del salario en función del incremento de la producción industrial, la participación del trabajador en las utilidades y la democratización del capital mediante la sociedad anónima por acciones, que permite el acceso a la empresa de los pequeños accionistas, son medios que contribuyen tangiblemente al alza de los niveles sociales $y$ del poder adquisitivo de obreros $\mathrm{y}$ empleados. Prodúcese de este modo una proliferación de njevas categorías y situaciones sociales intermedias en el mundo de los trabajadores, con tendencia a una gradual aproximación o ascenso al mundo del empresario.

Paralelamente, el inmenso volumen de la producción mundial, la expansión y multiplicación de los mercados de consumo por obra del progreso y del aumento de la población y la facilidad de los medios de comunicación estimulan las actividades del comercio, en grande y pequeño radio, $\mathrm{Y}$ favorecen el desarrollo de una variada burguesía cuyas escalas van desde el pequeño propietario agrícola hasta el comerciante de modesto capital, el experto hombre de negocios, banca y bolsa y el fabricante de mercado interno. Toda una gama, en suma, de gentes de condición mediana que, junto con los trabajadores ascendidos por su bagaje técnico más allá de su propio "status", pasan a enriquecer en escalones múltiples la llamada "clase media".

Al margen ya de los aspectos económicos, le ha tocado a nuestro siglo recoger la olvidada doctrina del Evangelio sobre la dignidad humana y la igualdad fundamental de los hombres, debido al recio impacto de la revolución política e ideológica comenzada en las postrimerías del siglo XVIII, continuada durante todo el siguiente. El problema social ha cobrado con ello una fisonomía nueva que abarca, además del económico, otros aspectos más elevados de orden cultural, político y espiritual. En otros términos "el problema social de nuestros días es el problema de la persona humana en la integridad de sus dimensiones $\mathrm{y}$ de sus aspiraciones, como un sujeto a quien atañen exigencias de justicia que han de serle reconocidas cualquiera que sea el grupo social en que esté ubicado. En punto a dignidad específica y a respeto de sus atributos, la persona humana no sufre una catologación de sus individuos en "clases". Por consiguiente, frente al hecho de la existencia de clases o escalones sociales en razón de situaciones externas imprescindibles para el desarrollo orgánico de la sociedad, se preconiza una política que, en medio de las inevitables diferencias, salve y preserve los derechos primarios de la personalidad. Áplicada esta política al mundo del trabajo ha tenido expresión en nuevas instituciones legales de promoción y defensa del trabajador, tales como la seguridad y la asistencia sociales, los organismos de salud pública, el contrato colectivo de trabajo, el sindicato, el impuesto progresivo sobre la renta que revierte en beneficio popular una parte de los beneficios de la empresa $\mathrm{y}$, sobre todo, la educación pública gratuita que despierta $y$ afirma la conciencia cívica del hombre $\mathrm{y}$ lo capacita para aspirar a un mejoramiento en su "status" de clase. Esta nueva realidad no solamente facilita la tecnificación. 
especializada del obrero para adaptarlo a las exigencias actuales de la industria, sino que origina y promueve una gran movilidad o circulación social, vale decir, un frecuente trónsito de los individuos de una clase $a$ otra, con plausibles consecuencias de elevación de su nivel económico y cultural. De este modo se descubren ya los atisbos de una creciente ósmosis de clases, lograda por un proceso de multiplicación de escalones intermedios y de aproximaciones recíprocas que tienen su origen en la creación de intereses comunes o en el hallazgo de puntos de coincidencia. Los límites tajantes entre las dos antagónicas clases tradicionales se desdibujan, pues, y se transforman en un mosaico de muchas nuevas piezas ensambladas entre sí y en cierta medida solidarizadas dentro del plano del bien común.

Todo lo cual nos lleva a concluir que, en la comunidad social contemporánea, resulta muy difícil y acaso imposible pretender ajustar la realidad de esos elementos humanos dentro de un esquema rígido de clases. Estaremos más cerca de la verdad si contemplamos el conjunto social como una superposición de estratos múltiples, como una concatenación de grados o categorías, o, mejor, como un agrupamiento de sectores diversos, como una concurrencia de grupos varios, con características propias, económicas, culturales, raciales o consistentes en modos peculiares de vida y costumbres, y a quienes liga un vínculo complejo de unidad gecgráfica, de intereses recíprocos $\mathrm{y}$ comunes fines sociales. Personalmente prefiero, en lo tocante a terminología, el empleo del vocablo "grupos" o "agrupaciones", porque descarta los conceptos de superioridad e inferioridad que van inhíbitos en la idea de "estratos" o "grados"; ya que aunque sea innegable que algunos de entre esos grupos disfrutan ex-facto de mayor poder económico o de mayores privilegios que los otros, a los cuales se sienten superiores, no es menos cierto que el factor económico no es el único en determinar la importancia de los grupos, pues concurren para medirla otros factores igualmente sustantivos, como el esfuerzo manual, los conocimientos técnicos, la masa numérica, la gravitqción sindical, etc., de donde resulta que el fenómeno de la producción no es el fruto exclusivo o predominante de una clase. sino resumen paciente $y$ efecto coordinado de varios entes coautores, igualmente indispensables o básicos para el proceso productivo.

Ciertamente, y pese a estas reflexiones, no puede negarse que, en el hecho, subsiste todavía en la realidad económica de nuestro tiempo ese dualismo social entre los poseedores de riqueza y los que carecen de ella, ese evidente desequilibrio en la distribución de lo bienes que riñe con los dictados de la justicia distributiva. Pero la propia intensidad con que hoy en día se proclaman y exigen las reivindicaciones económico-sociales está revelando que, al influjo del despertar de la conciencia de clases, el proceso de rectificación está en marcha. El fenómeno descrito de la multiplicación de los estratos o grupos sociales, de su creciente movilidad y de la atenuación de las distancias entre ellos, sirve para demostrar que aquel proceso evolutivo inexorable se orienta hacia soluciones de justo entendimiento. $Y$ hay que reconocer, después de todo, que una fórmula de esta índole, evolutiva y de armonía se aviene mejor con el concepto de la solidaridad humana que la otra perspectiva de una lucha de clases violenta o revolu- 
cionaria para llegar por la fuerza a una nivelación de resultados borrosos e inseguros. Todo depende de la cordura con que las clases poderosas quieran entender a tiempo el problema $y$ rendir sus reticencias al consejo de la razón y de la fraternidad cristiana. (1).

\section{ESQUEMA EXPOSITIVO SOBRE LAS CLASES EN EL PERU}

\section{IV.-Peculiaridades del problema de clases en el medio social peruano.}

El esquema general que hemos presentado en el acápite precedente sobre el panorama de las ciases en el mundo industrial contemporáneo no corresponde exactamente -hay que advertirlo- a la realidad sociológica de países sub-desarrollados como el Perú, donde el incipiente desarrollo de la industria no ha permitido aún una copiosa sub-división de clases, ni una intensa movilidad entre ellas, ni una elevación verdaderamente apreciable de los niveles económicos de las capas populares.

$Y$ es que en el Perú concurren ciertos factores peculiares que han contribuído al retardo de nuestro proceso sociológico en comparación con otros países latina-americanos que nos han tomado la delantera. Señalaremos, a título de ejemplos, los que siguen:

a) La situación confusa del elemento racial, en el cual no ha logrado todavía ubicación precisa lo que es pura y auténticamente "indio" en medio del variado e híbrido conjunto de lo mestizo, lo cholo, lo zambo o mulato $y$ el injerto de cepa oriental; sin contar las variantes que en el sector do raza blanca introduce la ascendencia española, italiana o anglo-sajona. El tipo del mestizo de la costa es bastante diferente del de la sierra. Mestizos con fuerte proporción de blancos conservan la indumentaria indígena; $e$ indios sin huellas de mezcla alguna hacen vida civilizada entre los blancos. A cada una de estas variedades raciales suelen corresponder determinados caracteres de educación, hábitos y sistema económico. Preséntase, así el Perú como un mosaico de pigmentos, como un verdadero crisol de razas que no han alcanzado todavía su estable sedimentación; y esta amorfía racial, al infundirse en los estratos de la población, dificulta grandemente cualquier intento de delimitación rigurosa de las clases sociales.

b) La fuerte proporción que alcanza la población aborigen no civilizada o en lento curso de civilización, cuyo aporte a la producción nacional es deficiente y rudimentario y cuyas limitadísimas necesidades de consumo reducen y hacen anémico el intercambio comercial en las áreas indígenas, limitando, por ende, la expansión industrial interna.

c) La perduración del espíritu colonial en la era de la República. Por largos años hemos preferido, como en la Colonia, seguir siendo produc-

(1) Parci la elaboración de este parágrafo han servido de tuentes de información, entre otras, los trabajos de la XXXI Semana Social de los Católicos de Italia, Bari, 21 a 28 de setiembre de 1958. 
tores de materias primas, fácilmente negociables en el exterior, antes que transformadores de nuestros productos en manufacturas de una industria autónoma. Y pudo mucho en esa preferencia la ley del menor esfuerzo: el razonamiento de que la exportación agrícola, lanar y minera era empresa de pocos riesgos $Y$ gastos mínimos de explotación, dada la inverosímil baratura, cuando no la gratuidad, de la mano de obra indígena, condicionada al mantenimiento del peón aborigen en su condición primitiva de servidumbre y de ignorancic. Nada se hizo por eso, para elevar los niveles sociales y culturales de los trabajadores indígenas ni para interesarlos en la producción. Fue menester que la experiencia de la Primera Guerra Mundixl, agudamente acentuada en la Segunda, nos pusiese delante de los ojos la fría rigidez con que las potencias industriales ponían precio inexorable $\mathrm{y}$ en veces no remuneraiivo a nuestros productos de exportación, para que despertáramos francamente al propósilo de industrializar el país y de disminuir el dispendio de divisas-oro en mercancías de consumo doméstico manufacturadas en el extranjero con nuestras propias materias primas. Por desgracia el tiempo perdido no se recupera fácilmente en esta clase de procesos.

d) Otro factor de lentitud en la evolución de las clases sociales en el Perí ha consistido, sin duda, en los desfavorables caracteres de nuestro "habitct" geogrófico, grandemente extenso en su superficie, hostil y rugoso en su topegrafía, árido en su faja costera, insalubre y poco menos que impenetrable en su zona selvática, $y$ con arduos problemas por resolver en punto a transportes internos. Todo esto significa lucha recia con los obstáculos de la naturaleza, alto costo en las obras dirigidas a superarlos, lento progreso en el aumento de las áreas agrícolas; y, desde el punto de vista demográfico, escasez de contacto humano con las regiones apartadas, aislamiento de pueblos mal ubicados, primitivismo en sus costumbres, migraciones en busca de regiones mejor dotadas de recursos, concentración de poblaciones en las ciudades con abandono de las zonas rurales, permeabilidad reducida en el trasiego de razas y de clases.

Cabe señalar, como una causal más de atraso en el avance socioeconómico. nuestra recalcitrante inestabilidad política, a través de muchas décadas de golpes de Estado, caudillismo y dictaduras. La discontinuidad de la democracia lastima el crédito exterior, ahuyenta la confianza del inversionista, interrumpe la normalidad de los negocios privados, introduce la versatilidad personalista en el manejo de la administración pública $y$ echa por tierra cualquier planteamiento económico serio con proyección a largo plazo. Sicológicamente, esta tendencia, distrae al ciudadano de la preocupación por los motivos permanentes del trabajo, la hacienda y cultura, para conducirlo al afón extremoso de la política y al cómodo distrute de la burocracia.

Estos $y$ otros factores han mantenido entre nosotros ciertos aspectos de organización feudal y han retardado el impulso de la renovación de las clase's. Sin embargo, en las últimas décadas no hemos sido insensibles al ritmo de progreso industrial desarrollado en todo el mundo. Con la presencia del capital foráneo traído por las perspectivas del país semicolonial, y merced $a$ un evidente cambio de postura del capital doméstico, que va per- 
diendo el temor al riesgo a medida que se persuade de nuestras grandes posibilidades, la industrialización ha adquirido en el Perú un apreciable volumen, que tiende $\alpha$ incrementarse. Infortunadamente, este fenómeno no cabe duda que se circunscribe a la Capital y en reducida escala, a unas pocas ciudades más: el resto del territorio no ha ingresado aún a la etapa industrial. Como consecuencia, es sólo en ciertas ciudades, y sobre todo en Lima, donde el problema de las clases asume contornos modernos $Y$ donde empiezan a darse casos y manifestaciones de definida división del trgbajo, de especialización profesional y de movilidad social o tránsito de un estrato a otro. En los demás lugares del país, en el agro, y aún -bajo ciertos aspectos- en la Capital misma, las agrupaciones de la población conservan todavía su semejanza con los antiguos "estamentos", sectores enraizados en su vieja tradición, ensimismados, retraídos, dominadores y egoístas los unos, próximos los otros a una paciente condición servil.

\section{V.-La Clase dominante: grupos sociales que Ia integram.-La aristocracta Y el poder económico.}

Según el esquema clásico, deberiamos agrupar la población humana del Perú en tres clases muy netas: alta, proletaria y media. Sin embargo, hemos dicho que esta división teórica no coincide con la realidad de nuestra época, en la cual se presentan estratos o grupos varios susceptibles de catalogarse dentro de una misma clase, o en el lindero de dos clases, pero distintos entre sí.

A la luz de este último criterio, podemos decir que en un examen tentativo de lo que sería nuestra clase dominante, descubrimos como más característicos dos grupos que poseen perfiles propios, aunque estén recíprocamente muy próximos: el grupo aristocrático y el que posee y ejercita el poder económico. Aristocracia y dinero.

El grupo aristocrático se remonta a los días de la Colonia y se vincula a la existencia del Virreynato. Familias de la nobleza o con ejecutoria de hidalguía vinieron a establecerse en Lima y otras ciudades principales, ya para el desempeño de funciones de la Corona, ya en busca de situaciones alentadas por reales privilegios. La concesión de encomiendas a muchos de estos Señores sentó las bases del latifundio en díversas régiones del territorio y particularmente en la costa; al paso que en las serramías la tenencia de la tierra fué de preferencia adjudicada en premio de servicios a conquistadores erigidos en encomenderos. En realidad, durante el primer siglo de nuestra independencia la agricultura de la costa fue un dominio de hacendados aristócratas. Poco a poco la propiedad ha cambiado parcialmente de manos, $y \propto$ por ventas individuales, ya por la concentración de fundos en grandes consorcios de explotación mixta, agrícola e industrial. Pero fundamentamente, el precio agrícola costeño conserva aún en varias provincias su sello de patriarcado aristocrático.

Originalmente, la aristocracia peruana presentaba los mismos carac. teres que otros países han tipificado a esta clase social: acendrado espíritu religioso, estrictos cánones de costumbres, orgullo de la alcumia, distancia 
rigurosa respecto de las demás clases, sin perjuicio de un cordial espíritu paternalista en el trato con los servidores del hogar y de la hacienda. Pero, al mismo tiempo, un concepto arraigado de la propia superioridad, y un repudio incomprensivo de las conquistas sociales de las clases humildes en nombre de los fueros de la persona humana. Casi en forma instintiva, tras el peón se evocaba al siervo de la gieba. Como remate de esta posición de altura, la figura del aristócrata gozaba en el país de una aureola de respeto reverencial por parte de las otras clases, que veían en él, no sólo al patrón, sino al conductor cívico predestinado y por lo tanto, indiscutido. La vocación política del aristócrata gozaba del respaldo del pueblo.

Posteriormente, bajo el influjo de las nuevas formas de vida, algunas de estas cerradas características se han atenuado o estón en trance de radical transformación. Son admitidas las uniones matrimoniales con elementos del sector adinerado sin la vieja exigencia del título de sangre. Los hijos de aristócratas son, hoy, en buenc proporción, demócratas convencidos y accesibles. Por haber venido a menos sus fortunas, familias de rancio abolengo han trasmigrado a las capas medias para ocupar situaciones en la burocracia, en profesiones liberales o como pequeños rentistas. $\mathrm{Y}$ hay aristócratas progresistas que han penetrado resueltamente en el campo de los negocios industriales, modernizando la organización de sus em. presas, para convertirse en plutócratas. Funciona, pues, ya en este sector, una visible movilidad de clase y una evidente descaracterización del sentido aristocrático.

En cuanto al poder económico dentro de la esfera privada, se reducía originalmente en nuestro país a la riqueza inmobiliaria.

Los ricos eran los grandes terratenientes que vinieron a disfrutar en la república de las asignaciones y encomiendas del período colonial. Compartían el latifundio los aristócratas y los descendientes de los soldados de la conquista. Por entonces no había aún aparecido la industria: como en el antiguo incario, nuestro pueblo seguía siendo agricultor $\mathrm{y}$ pastoril. Esta situación duró algunas décadas. Se cultivaba el pan llevar. Para sembrar arroz y caña se trajo peones japoneses y africanos, bajo la presunción de la inadaptabilidad de nuestros aborígenes al clima tropical de la costa. En ese entonces el indio vivía firmemente incrustado en sus ayllus serranos. Los ingenios de azúcar y los alambiques de alcohol señalaron los atisbos de la transformación industrial. Luego vino el algodonero a hacer sentir las pulsaciones del mercado exterior. En la puna, los hacendados exportaban lanas pobres a cambio de libras esterlinas que empozaban en el Banco de Londres. La ganadería criolla, bajo el látigo del arriero, surtía a duras penas de carne a las poblaciones.

Pero más tarde, respondiendo a la nueva conformación económica del mundo " había de advertirse un movimiento, tímido en un principio, más pujante muy pronto, hacia la industrialización general del país. La agricultura perfeccionó sus ingenios industriales para el tratamiento de la caña. Con marcada reticencia inicial de no pocos hacendados, capitalistas avizores instalaron plantas fabriles para tejer nuestros algodones $\mathrm{y}$ nuestras lanas, artículos que, sin embargo, siguen saliendo todavía en fuerte proporción al exterior bajo su forma de materia prima, a trueque de un importante 
aflujo de divisas. La ganadería del centro y del sur ha mejorado notablemente sus planteles mediante sucesivas etapas, primero de importación de reproductores y de hembras de sangre fina y luego de utilización del sistema de inseminación artificial, con lo cual la producción de lanas y de leche se eleva considerablemente. En otros sectores de la industria, la minería ha fundado poderosos establecimientos industriales para el beneficio y transformación de minerales y petróleo; van surgiendo las plantas de energía hidráulica, día a día las industrias manufactureras, químicas $y$ eléctricas en pequeña y mediana escala, tienden a cubrir las necesidades cada vez más variadas y crecientes de nuestro medio económico-social; $y$ proliferan por todo el territorio las empresas de transporte. Por su parte, el Estado no ha podido ser indiferente a este impulso vital de la producción, y ha atendido a la creación de bancos de fomento en las actividades agro. pecuaria, industrial y minera, sin perjuicio de afrontar los aspectos viales para facilitar las comunicaciones de intercambio.

Paralelamente a este repunte de la actividad industrial, ha sobrevenido un ensanchamiento del campo financiero. El capital foráneo se ha invertido en negociaciones industriales y comerciales de apreciable envergadura. La banca ha alcanzado un desarrollo sorprendente. Se han exten. dido las empresas privadas de seguros. Funciona el crédito internacional. El crecimiento de las ciudades abre largas perspectivas a las inversiones inmobiliarias. $Y$ una gama variada de instituciones privadas, como las Cámaras de Comercio y de Industria, la Sociedad Nacional Agraria, ligas de exportadores, de comerciantes, de aseguradores, etc., cautelon con riguroso celo los intereses de ese ímplicito consorcio de los poderes del capital privado.

Los hombres que han forjado este grupo tricéfalo de la gran producción. industrial, el grueso comercio importador y las finanzas privadas, son de extracción social heterogénea: hay allí aristócratas de cepa agraria, peruanos de la clase media que en ardua carrera de trabajo han ascendido a la fortuna; inmigrantes que con su esfuerzo han alcanzado sobresalientes situaciones económicas e inversionistas extranjeros que, por sí o mediante sus representantes, dirigen en el país el desarrollo de. sus cuantiosos recursos. Esta diversidad de condiciones personales tiene un denominador común que caracteriza "la clase": el alto poderío económico; el afón de fructificación del dinero como instrumento de influencia y de comodidad, la solidaridad en defensa del' predominio social.

Ya se observa en este grupo - como en el de la aristocracia ruralla misma cordial bonhomía paternalista hacia los estratos inferiores de la sociedad. Aquí la lucha es más recia, la competencia más reñida, el apremio de los plazos más angustiosos, el valor del tiempo mejor cotizado, las reivindicaciones del trabajador más exigentes que en la faena campesina $\overline{\text {. }}$ Por eso en el sector económico poderoso la actitud es más fría, el criterio más duro, el sentimentalismo más raro, más natural el hábito de las fuertes ganancias por la rópida circulación que dan a su dinero, y más encarnizadá la defensa de la inversión. En los últimos tiempos, sobre todo, y sin que el fenómeno sea, por cierto, privativo del Pená, parece haberse despertado en algunos sectores de esta clase un absorbente sentido materialista de la 
existencia. Por lo demás, en cuanto a su comportamiento social privado, los miembros de este grupo del dinero son elementos de orden y de fecunda iniciativa personal, con altos dones de inteligencia y voluntad de acción, con laudable apego a la vida familiar $y$ una indiferencia religiosa pese $\alpha$ su cristianismo formal. Tienen rivalidades entre sí; pero, saben posponerlas a la hora de defender los intereses comunes.

Existe, además, otra característica que es propia de toda la clase dominante del Perú, incluyendo la aristocracia agraria y el sector de la fuerza económico-financiera, y es su poder de influencia en la política del país. Esa clase daminante es, también, clase dirigente. Desde muchos años atrás, mantiene activos sus resortes y su ingerencia en el seno de los Gobiernos, en los Parlamentos, en las dependencias de la Administración Públi$\mathrm{Ca}$, en las instituciones oficiales de producción, de crédito y moneda, en el mercado de cambios, en las entidades acotadoras y recaudadoras de impuestos y hasta en los organismos electorales. Acaso el único sector donde ha perdido predicamento es en el de los partidos políticos, por la extinción del antiguo Partido Civil y por el aura joven que anima a los partidos de reciente creación. A través dé casi todos los períodos gubernamentales, ha correspondido $\alpha$ esta clase, directo $o$ indirectamente, l $\alpha$ orientación de los negocios públicos y el contralor de los sistemas económicos; y no pocas veces sus arcas han aliviado momentáneamente las penurias del Erario fiscal. Por eso cabe decir con rigurosa propiedad, que la alta clase adinerada del Perú constituye una plutocracia en el sentido que le atribuye la etimología griega de la palabra: "Gobiemo de los ricos", "preponderancia de los ricos en el Gobierno del Estado".

Sin emburgo, esa clase dirigente no ha llegado a ser una verdadera clase directora, en el sentido de imprimirle al país un tono de vida concorde con el avance de los tiempos y con la idea cristiana. Nuestra estructura interna, en lo económico y en lo político-social, padece un atraso de muchas décadas; $Y$ el contrasté existente entre este estado anacrónico $y$ las impacientes exigencias actuales de la conciencia popular suscita un clima de tensión peligroso y dañino. Nos toca a los católicos contribuir a aliviar aquellas tensiones, enunciando los remedios que tiene señalados la doctrina de la Iglesia.

Prácticamente, la realidad descrita sobre la clase dominante en el Perú corresponde a la Capital de la República y g unas cuantas Provincias en que se siente el imperio de las grandes familias y del volumen pecuniario. En el resto del país, la aristocracia provinciana no alcanza por lo general a reunir los atributos de un verdadero poder económico: sigue siendo el estamento severo, afable y a veces jactancioso de otros tiempos. El capitalista lugarareño ejercita su función de dominio dentro de una área circunscrita ya como patrón en el latifundio. ya como gamonal en ciertas comarcas, ya como propietario acomodado, industrial mediano o comerciante próspero en ciudades y pueblos. Desde hace algunos lustros, fuertes entidades mercantiles de la Capital han extendido sus negocios a otras plazas del país y han fundado allí sucursales que compiten ventajosamente con el gobierno local. La gran empresa prosigue, pues, su programa de expansión a todo el país' 


\section{VI-La clase popular.-Sus varios grupos, - Campesinos, obreros Y peque- ños crtesanos.}

Si intentáramos una enumeración de los grupos que integran nuestra clase popular, diríamos que para ello es indispensable acudir a la ayuda de un criterio geográfico; porque la influencia de nuestra geografía es decisiva en la distribución de las ocupaciones y en la calidad de los hombres de trabajo. Partiendo de esta base, podemos mencionar como grupos competentes de esta clase a los campesinos de la costa, a los campesinos aborígenes de la sierra -en su doble posición de colono de hacienda y de miembros de comunidades-, a los aborígenes de la selva, a los artesanos de mínima categoría y a los obreros de la industria en sus variedades urbana y rural,

Los campesinos que trabajan en la costa, desde Tumbes hasta Tacna, no tienen todos una situación pareja. Presentan, por el contrario, diferencias apreciables de grupo a grupo, debido a la tremenda indefinición de sus elementos raciales y al grádo siempre cambiante de las tensiones colectivas. Por eso, los criterios o patrones mentales que habremos de usar para nuestras clasificaciones y agrupamientos, son forzosamente elásticos y pueden no ser completos. Vivimos, a este respecto, en un período de indiscutible transición.

Desde el punto de vista racial. los campesinos de la costa son ahora en muy escasa properción indígenas puros, y prevalecen entre ellos los mestizos (mezcla de indio y blanco) y los "cholos" (con mayor dosis de sangre blanca que los mestizos), sin que falten, en escala mucho menor, los mulatos (mezclados de negro) y los injertos de chinos y japoneses. Tanto por esta calidad de elementos más próximos a la raza blanca que los aborígenes de la sierra, como por la posición geográfica de la faja marítima, más propicia que cualquier otra al influjo de la civilización y al contacto inmediato con sus avances, el hombre de campo de la costa es más evolucionado que el campesino aborigen de la sierra y percibe, a buen seguro, con una conciencia mós lúcida que ése, la inferioridad de la condición de su clase.

En cuanto a las tensiones colectivas, ofrécense en diverso grado, según las variedades de cada ambiente: así la tensión social suele acentuarse en los lugares donde actúan los sindicatos; y con frecuencia, los fundos poseídos por dueños individuales que viven en contacto con sus peones y conocen de cerca sus necesidades, gozan de ambientes menos tensos que los pertenecientes a empresas anónimas donde una fría rigidez es la pauta de la administración.

Económicamente, cabe agrupar por separado a los peones de las grandes haciendas modernamente organizadas; a los peones de haciendas, no importa de qué tamaño, cuya explotación es todavía rutinaria; y finalmente a los pequeños arrendatarios y yanaconas o aparceros que cultivan tierras ajenas por determinada merced conductiva o a trueque de una prestación de trabajo. 
En los dos primeros grupos funciona el régimen del salario; y aunque en los años recientes la escala de jornales ha subido -generalmente al compás del alza del costo de la vida-n puede afirmarse que el salario. está aún debajo de lo debido y llega a ser a veces insuficiente para la satisfacción de las necesidades familiares y de previsión del trabajador. En las grandes haciendas, la lucha sindical va corrigiendo esta pobreza de niveles; pero las deficiencias se agudizan en los fundos no evolucionados, sea por causa de la forma primitiva de la explotación, de los mayores costos de producción, o de otros factores locales. De fuentes fidedignas, hemŏs obtenido en estos fundos promedios salariales de 6 a 8 soles diarios.

Por lo que hace a la vivienda campesina, comprobamos con agrado que en las grandes haciendas industrializadas han mejorado apreciablemente las rancherías o "colcas" de sus peonadas; pero en muchos otros fundos las condiciones de la habitación siguen siendo insalubres y paupérrimas, con ostensible nivel infra-humano. Por lo demás, no han llegado a cumplirse sino parcialmente las leyes vigentes que obligan a los dueños a sostener escuelas para los hijos de los trabajadores.

En cuanto al tercer grupo, los pequeños arrendatarios de la costa se ven precisados, por lo general, a pagar en moneda de sacrificio su empeño de conseguir parcelas o pequeños fundos dónde trabajan para la agricultura: la reata conductiva es alta casi siempre, y en abonarla invierten buena parte, acaso la mayor, del producto bruto de la explotación; teniendo que dividir el resto entre el pago de jornales y contribuciones, la adquisición de abonos y semillas y el presupuesto de subsistencia familiar; sin contar con las eventualidades de heladas, sequías, plagas y malos precios. Es típico el caso del valle de Arequipa, donde el valor de la reata de la tierra es sumamente elevado, en consecuencia con el altísimo valor de los predios agrícolas.

Por lo que hace al yanacona, leyes especiales han tratado de aliviar la condición de los labradores que se acogen a este sistema para conducir tierras ajenas; pero en el fondo, y pese a los medios de protección dictados, lo que es y seguirá siendo malo es el sistema en sí mismo, esto es, el hecho de compensar el aprovechamiento de las tierras con obligaciones que a la larga importan una vinculación o servidumbre respecto del propietario rural en que se suman el pago de una merced conductiva (más frecuentemente en frutos que en dinero); el reato de la persona del yanacón al fundo para contribuir al laboreo de las tierras que explote el dueño, y no pocas veces el compromiso de vender las cosechas al propietario, a precios prefijados o invariablemente bajos, en pago de habitaciones recibidas para el proceso de explotación.

No cabe duda de que entre los medios de lograr una reforma útil en el agro peruano se cuenta la necesidad de sustituir o proscribir este inveterado sistema de arrendamientos o aparcerías de yanaconaje que extrae de la entraña de la tierra una doble renta: para el propietario en forma de canon, partida de frutos o prestación de trabajo del campesino; y para el arrendatario o yanacón en forma de expensas domésticas o presupuesto familiar de subistencia. Por generosa que la tierra sea, no alcanza su largueza a abastecer esta duplicada demanda. Hay que buscar formas 
legales que conduzcan al desideratum de la renta única para el cultivador de la tierra.

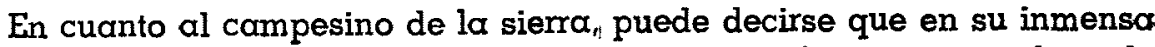
mayoría pertenece a la raza aborigen, y aunque está desparramada a lo largo del territorio nacional en todas las mesetas y quebradas de la Cordillera de los Andes, ofrece como zona de mayor concentración demográfica la meridional del país, en los departamentos de Puno, Cuzco, Apurimac y una parte de Arequipa. En la zona del Centro y sierra de Lima Junín y Huánuco), el hecho de la proximidad a la Capital del país, el establecimiento de grandes empresas mineras de beneficio y la existencia de poderosas haciendas ganaderas son factores que han hecho evolucionar considerablemente el panorama agrario; y el nivel salarial del peón indígena ha mejorado sin dejar de ser exiguo. Por otro lado, las comunidades indí. genas han alcanzado un cierto grado de civilización que empieza a traducirse en algunas de ellas en la modernación de sus equipos agrícolas y en la formación de cooperativas de crédito y producción. Pero el agro serrano del Sur se mantiene todavía en una etapa social de gran atraso, en contraste con el visible desarrollo de la etapa técnica en su industria ganadera.

Tomando como ejemplo el Departamento de Puno, que es el más densamente poblado (encima de 800,000 habitantes, de los cuales se calcula que al rededor del $90 \%$ pertenecen a las áreas rurales) encontramos que el campesino indígena estó repartido en tres grupos: los pequeños agricultores de los "ayllus", los colonos de las haciendas, y los pequeños propietarios indígenas.

Los labradores indígenas de los ayllus, principalmente instalados en los alrededores del Lago Titicaca, constituyen el núcleo demográfico más numeroso (2). No es nuestro propósito traer a este trabajo la descripción sociológica del ayllu, institución de ancestro incaico modificada luego parcialmente por influencias sociales y religiosas de la Colonia y de la República. Diremos sólo, dentro de los fines de nuestro estudio, que el doble vínculo de cohesión entre los miembros del ayllu tradicional, a saber: el vínculo hereditario o de sangre y de carácter comunitario de la tierra, ha experimentado con el correr del tiempo importantes atenuaciones. Sea por razón de uniones matrimoniales con miembros de los otros ayllus, sea por actos contractuales que escapan al poder fiscalizador de nuestras leyes, se dá en la próctica el hecho de ser incorporados a un ayllu individuos que le erou extraños. $Y$ contra lo que puáiera creerse, la tendencia de la tierra en el actual ayllu puneño no funciona bajo un régimen de propiedad común, sino de propiedad privada, ejercida individualmente por cada uno de los jefes de familia poseedores de los varios lotes en que el ayllu se divide (3). Este dominio individual de la tierra se traduce no pocas veces, al margen de la ley, en enajenaciones de esos lotes a extrañost quienes

(2) Las $7 / 8$ partes de la población rural, según el Inqeniero Hernán Augusto B.

(3) El dueño de cada lote vende libremente sus productos o los aprovecha para stu. climentación. 
quedan por tal hecho involucrados dentro del grupo de sus miembros. Donde radica propiamente el sentido comunitario del ayllu $\mathrm{Y}$ su vinculación con el pasado es en la forma de explotación de la tierra para los fines de la producción: las faenas agrícolas principales de arado, siembras y cosechas de cada lote se realizan en común, vale decir, con la cooperación no remunerada de los demás miembros del ayllu dueños de los otros lotes, y por cierto, con cargo de reciprocidad. Los productos agrícolas (papas, cebada, quinua, cañahua, etc.), sirven para la alimentación de los propios comuno ros, dentro del régimen autórquice de economía cerrada que allí predomina: y la esquila del ganado que crían en muy pequeña escala, les dá la lana paro sus vestidos.

Factores diversos influyen, sin embargo, para que ese régimen del ayllu diste mucho de ser económicamente eficiente. La extrema subdivisión de los lotes y parcelas por el constante crecimiento de las familias y las fragmentaciones hereditarias pulverizan la propiedad y mantienen en nivel muy reducido el patrimonio personal de los miembros de la comunidad. La ausencia de métodos técnicos y la falta de equipos agrícolas modernos limitan en forma desastrosa la producción de la tierra y de los ganados y, por ende, los abastecimientos de los pobladores. Por último, la presión demográfica procedente de todo el altiplano, sea por el aumento general de la población, sea por el rebalse de colonos expelidos de las haciendas, viene a gravitar en paite sobre los ayllus, originando nuevos fenómenos de tensión económica y de congestión social. Hay quienes piensan que, pese a todo, el nivel general de vida de los comuneros de los ayllus es superior al de los colonos de las haciendas o latifundios del Collao, y que comienza a despertarse el interés por mejorar la calidad del ganado nativo. Aún ésto por cierto, no lo es menos que la vida del campesino indígena discurre en los ayllus enteca y miserable, sin grandes perspectivas de espontáneo mejoramiento económico y lo que es más penoso, sin ningún horizonte espiritual. Puntos esenciales de cualquier plan de reforma agraria en esta región deberían ser el fomento de las cooperativas agrícolas y la implantación de un sistema adecuado al crédito que, al incrementar la producción, diese con ello cabida al aumento de los consumos y a la expansión del intercambio comercial, hoy reducido en gran parte a un primitivo sistema de trueque.

Para saber explicarse cómo funciona el sistema de colonato indígena en el Departamento de Puno, hay que describir, siquiera sea someramente, el territorio en que ese sistema se aplica.

El altiplano puneño está ocupado en mós de $60 \%$ de su extensión por numerosas haciendas ganaderas, grandes y medianas, de propiedad particular, muchas de las cuales constituyen típicos latifundios sin explotación intensiva. Algunas de ellas sobrepasa las 10,000 hectáreas de extensión; pero el área de las haciendas consideradas como las menores de entro las medianas se acerca a las 1,000 hectáreas. Muchas triplican y cuadruplican esta cifra. (4).

(4) Datos del Ingeniero señor Augunto. 
Dentro de estas superficies, las porciones dedicadas a la agricultura propiamente dicha son muy reducidas $\mathrm{y}$ ostentan cultivos de secano consistentes en plantas alimenticias adecuadas al clima de la región. Todo el resto de las haciendas es absorbido por la explotación ganadera, utilizándose los pastos naturales (icho o paja de puna) que en varios parajes presentan síntomas marcados de degeneración orgánica.

En comparación con la superficie total de las tierras de los ayllus - comunidades, se calcula, grosso modo, que el área de las grandes haciendas particulares es tres veces mayor. Sin embargo, la población campesina que trabaja en tierras de ayllus representa aproximadamente el 90 por ciento de la población rural del departamento, mientras el número total de propietarios de haciendas alcanza apenas a menos del medio por ciento de esa población. Estos datos permiten formar un concepto sobre la gran desigualdad existente en la distribución de la propiedad rural en esta zona del Perú. (5).

Tal es el territorio en el cual tiene vigencia el sistema de explotación agraria conocido bajo el nombre de "colonato".

Por ser sobrado conocidas, sería ocioso describir en este trabajo las normas consuetudinarias del contrato de colonato, al cual se ajustan las relaciones del propietario, de un lado: y del pastor indigena, de otro, en las haciendas del altiplano. Basta, para nuestros fines, hacer la apreciación de cómo influye ese régimen contractual en la ubicación social del aborigen como individuo de una clase.

Hemos de advertir, de entrada, que no es exacta la afirmación do quienes atribuyen $\alpha$ ese régimen un carácter exclusivamente unilateral de explotación del indio. El de colonato es un contrato sin forma escrita pero bien caracterizado entre los de título oneroso, en el cual hay prestaciones recíprocas: el colono compromete su tiempo y su trabajo para el pastoreo del ganado del dueño y para determinadas faenas agro-pecuarias del fundo a las cuales debe llevar también cierto número de miembros de su familia; y recibe, en retribución, el disfrute de una parcela cuyo cultivo le procura sus alimentos vegetales: el usufructo de una porción o lote de pastos para hacer pacer su propio ganado en determinada medida; el derecho temporal a construir su cabaña en la parcela a él asignada, para vivienda de su familia; $y$, en algunos casos, no en todos, una remuneración pecuniaria mínima y más bien simbólica, por la labor de pastoreo y por las faenas a las cuales concurre. No es el caso de establecer si existe o no entre estas prestaciones una equivalencia aproximada. Lo que importa es verificar a la luz de la experiencia sí, por su índole misma, este régimen de trabajo aporta al colono elementos que contribuyan a la promoción de su personalidad y a la obtención de un nivel de vida razonablemente humano.

Desgraciadamente, la respuesta de los hechos es negativa. En más de una centuria de vida republicana que llevamos, el colono indígena ha avanzado muy poco o no ha avanzado en la formación de su conciencia

(5) No pueden ser muy diferntes las cifras de la zona agrícola de la costa, donde abunda también la gran propiedad concentrada en pocas manos. 
de hombre, en su horizonte intelectual y religioso, en su facultad de libre iniciativa, en sus hábitos de higiene, en su manera de alimentarse, en su poder adquisitivo o grado de solv́encia económica. En algunos casos, su dramática oscuridad mental lo pone muy poco por encima de los animales que apacienta. En otros, el beneficio de la escuela no ha llegado a su alcance y se mantiene analfabeto. En muchos otros, la enfermedad hace presa de él por falta de profilaxis o por insuficiencia de atención médica. En muchos más, el raquitismo y la degeneración racial amagan a él y a sus descendientes a causa de su exiguo y mal compensado régimen alimenticio, agravado por el uso del alcohol y de la coca. Salvo casos de excepción, el colono no puede aspirar a un mejoramiento sustancial de su posición económica, pues el pequeño comercio que a veces hace vendiendo los excedentes de sus productos (dspués de atendidos la alimentación y el vestido), sólo le procura utilidades mínimas que rara vez se traducen en el tránsito $\alpha$ un nivel social más elevado. En realidad, no aspira $\alpha$ consumir más, ni a producir más, porque desconoce las nociones de valor económico y de comodidad. Y finalmente, en todos los casos el colono es un ser que no conoce la libertad exterior, un confinado al servico de la hacienda, que no traspone sus linderos si no es para ahogar en la embriaguez de las fiestas pueblerinas la murria tórpida de su enfeudamiento.

Muy distinta habría sido la condición actual del colono aborigen si desde años atrós se hubiera estimulado en las haciendas sus facultades nativas de vigor $y$ de perseverancia mediante algún aliciente en su trabajo, y se hubiera tratado de ganarlo a la educación, a la sociabilidad y a un mejor conocimiento del mundo exterior y de las cosas y problemas usuales de la vida. Si se hubiera puesto empeño en liberarlo del uso del alcohol y de la coca. Si se le hubiera dirigido en la construcción de su cabaña para enseñarle a dotarla de mínimas calidades higiénicas. Si se le hubiera persuadido de que estaba en su interés mejorar el tipo de su ganado "huaccho" (o chusco) para obtener una mejor producción de lana, y se le hubiera facilitado gratuitamente el servicio de cruzamientos. Pero, en general, estas fóciles medidas fueron sistemáticamente ignoradas. Se temía, incluso, que una permanencia a firme en la hacienda despertara en el colono el instinto de propiedad, y se le obligaba por eso a cambiar anualmente la ubicación de su parcela agrícola y a volver a construir allí su cabaña, a fin de marcar objetivamente con esa vida trashumante el carácter provisorio de la posesión concedida. Se pensaba también en la inconveniencia de mejorar el ganado "huaccho" del colono, porque el ganado fino, más robusto, consume mayor cantidad de pastos, con lo cual se habría mermado la provisión alimenticia de la oveja del patrón. Pienso yo si no es factible idear cualesquiera medios que eliminaran el inconveniente: v.gr.: la reducción del número de ovejas de alta calidad permitidas al colono cuando asomara el peligro de una sobre-capitalización de la hacienda. En realidad, lo que ocurría es que, con la mejor buena fe del mundo, muchos de los hacendados no acertaban a pensar que el pastor indígena era, como ellos, una persona humana. Fra, solo un elemento de trabajo. La Colonia ha sobrevivido mucho tiempo en las mesetas de los Andes. 
Por fortuna, esta etapa oscura parece haber sido superada; y hoy son ya varios los propietarios de hacienda que tienen iniciada una tarea de dignificación del colono indígena $\mathrm{y}$ de mejoramiento del nivel de su estrato social. La tendencia que más claramente se insinúa es la de modernizar el régimen de la empresa ganadera sustituyendo gradualmente el colonato por un sistema normal de salariado en el cual el campesino indígena gane un justo jornal por su trabajo, sea como pastor, sea' como peón agrícola en las faenas periódicas del campo. Se ha divulgado, incluso, fin recientes publicaciones, el ensayo que desde hace pocos años viene haciéndose, en una hacienda del departamento de Puno, de una muy interesante concepción cuya finalidad es eliminar, a la larga, la tenencia de ganado "huaccho" por el actual colono, abriendo a éste, en cambio, la perspectiva de una holgada situación como bracero bien remunerado. $\mathrm{Me}$ diante esta fórmula, el pastor indígena recibe un jornal progresivamente mayor por el cuidado del capital ganadero del dueño, a medida que sar más pequeño el número de cabezas de ganado "huaccho" que ese mismo pastor posea en su majada: Así, el día que llegue a liquidar del todo su ganado "huaccho" comenzaró a percibir un salario normal muy apreciable. Hay además bonificaciones especiales en dinero por el mayor número de crías logradas en las pariciones correspondientes al hato de cada pastor; con lo cual, en buena cuenta, se hace a éste partícipe de la mayor utilidad del patrón. El sistema entraña una doble ventaja: aumento del poder adquisitivo del pastor, pues ya podrá manejar dinero por sí mismo, cosa que sólo ocurría en mínima proporción en el contrato de colonato; y creación de un estímulo en su ánimo para extremar sus cuidados en el ejercicio de su cargo, con la esperanza de una mayor ganancia si logra incrementar el ganado que custodia. Como al desaparecer el ganado "huaccho" del pastor, éste no tendría ya de dóndo proveerse de carne pará la alimentación familiar, la administración de la hacienda lo surte a precio de costo de éste $y$ otros artículos de consumo alimenticio mediante un almacén $Y$ proveeduría instalada al efecto. En cuanto al ejercicio de la agricultura, el nuevo sistema ha concebido la reunión de todas las parcelas o chacras de los pastores en un sólo terreno de mucho mayor superficie, el cual es trabajado en forma cooperativa por todos ellos en conjunto. Voluntariamente asociados, proporcionan ellos las semillas y realizan las faenas: $y$ la hacienda les proporciona los servicios de tractor y maquinaria agrícola.

Evidentemente, este ensayo representa un paso efectivo y digno de encomio hacia la elevación del nivel social del campesino indígena del altiplano. ¿Será éste el paso definitivo? He ahí la interrogante que ha de plantearse a cualquier proyecto de reforma agraria. La fórmula descrita convierte al indio campesino en asalariado y lo aproxima, con ello, a los moldes en uso del trabajo contemporáneo; pero al mismo tiempo le aparta de la posesión de la tierra, condenándolo virtualmente a no ser nunca propietario. Lo cual equivale a arrancarlo de lo que es su pasado y su tradición. A nadie puede ocultarse la vocación agraria del indio y su profundo apego a la tierra. Tampoco puede eludirse la consideración de que un gran número de los actualés propietarios de las haciendas del Collao no residen en la región ni trabajan personalmente sus fundos, sino a través 
de administradores o de técnicos comisionados suyos, $Y_{;}$en menor número de casos, a través de arrendatarios. Son propietarios ausentistas que reciben en su casa el fruto del feudo distante. Reflexiones son éstas que tendrán. que pesar, sin duda, en el espíritu de quienes deban afrontor en el Perú la revisión de nuestras estructuras sociales. Nadie puede disputar la legitimidad de su posesión a aquellos propietarios (de aqui o de allá, blancos - mestizos, puneños o foráneos) que han dado a sus haciendas el aporte de su esfuerzo personal, de su espíritu de iniciativa, de sus conocimientos técnicos $y$ de su calor humano, y que saben mantenerlas como verdadero laboratorio social en el que corren parejas el designio de provecho económico y el ensayo de recuperación moral y social del aborigen, con perspectivas de una humana elevación de sus niveles materiales y espirituales. Pero, allí donde el egoísmo y la incomprensión del problema se muestran reacios $\alpha$ toda innovación o donde perduran métodos de repudiable abuso o düreza, la ley misma se encarga de señalar los medios de trasmisión de la propiedad que permitirían asignar ésta a los campesinos aborígenes, con la adición de elementos crediticios $y$ de asistencia técnica del Estado para elevar sus índices de producción. Y ello, con la parsimonia exigida por toda obra o empresa en que está de por medio un problema social de tan compleja contextura. Son fatales en estos casos las improvisaciones y las impaciencias. No se improvisan ni la educación que el indio requiere para asumir sus nuevas responsabilidades sin peligro de un tremendo fracaso, que ya se ha dado en otras partes; ni los cuantiosos recursos económicos exigidos por proyectos de esta índole; ni la capacidad de medios técnicos necesarios para orientar la marcha de la reforma. En la mesura con que todos sepan afrontar la solución de este problema está el secreto de su éxito y el talismán de los beneficios sociales que reporte.

Apartándonos ya del altiplano y dirigiendo la visual a los Departamentos del Cuzco y Apurímac, encontraremos formas de explotación de la tierra anólogas a las ya descritas; pero los grupos campesinos de la raza aborigen y mestiza acusan un estado más primitivo $y$ de mayor atraso social que en Puno, debido a su mayor aislamiento y a la persistencia en esos lugares de un más cerrado sentido feudal en la mayoría de los propietarios. Hay allí también extensos latifundios y haciendas donde impera el régimen del colonato, al lado de pequeños fundos de agricultores particulares y de tierras de comunidades. La distancia a las capitales, las dificultades de fiscalización por parte del Poder Público y la fácil complicidad de las autoridades inferiores o locales, mantiene allí todavía en apogeo el reinado del gamonalismo. En los valles de la sierra del Cuzco y Apurímac, el campesinado indígena es dedicado a los cultivos tropicales: caña de azúcar, coca $y$, en más reducida escala, café y cacao. Los hacendados poseen alambiques para la destilación del alcohol. Resulta, asi, verdaderamente lamentable que en estas regiones tengan los indios al alcance de la mano los dos venenos que los degeneran $y$ bestializan: el alcohol y la coca. Es hora ya de que una consciente actitud de los dueños. o una acción directiva del Estado, decida una transformación del régimen agrícola de esas zonas, reempliazando los temibles y nocivos cultivos por otros muchos más útiles y sin duda igualmente remuneratorios, 
como son los de cacao y café, fácilmente exportables; los de maní y girasol, con alto rendimiento de grasas; $y$ el del té, planta que viene extendiéndose apreciablemente sobre todo en el valle de la Convención y cuya calidad $\mathrm{y}$ buena preparación industrial son augurios de un próspero porvenir en los mercados de consumo.

No resultaría completa la descripción objetiva que acabamos de hacer de los grupos campesinos de la sierra si no apuntóramos un factor sociológico que estó influyendo poderosamente en la creciente depauperación de este sector popular. Nos referimos al aumento vegetativo de la población del Perú, que se calcula en la proporción de 24 por mil al año, lo cual implica que para 1965 nuestro país habrá aumentado en dos y medio a trés millones de habitantes. (6) Naturalmente, la mayor masa de este aumento conesponde a la raza indígena, que representa más de la mitad de la población del país. La gravedad de esta incidencia puede apreciarse si se considera que el censo de 1940 registró en el Departamento de Puno 548,371 habitantes, y el cálculo estimativo de la Dirección Nacional de Estadística para julio de 1957 atribuye a esa circunscripción 766,600 habitantes. Y esto con un criterio exageradamente prudente: las cifras verdaderas son mucho mayores. Los efectos de este rápido incremento de población viene sintiéndose desde hace algunos años en el altiplano puneño: sus ciudades se pueblan cada vez más; los ayllus no pueden soportar su mayor congestión demográfica; las haciendas no admiten nuevos colonos ni hay en ellas posibilidades de infiltraciones masivas; la desocupación cunde; y ante ésta realidad dramática, el rebalse humano está buscando vías de salida $y$ se derrama en dirección a Provincias semi-selváticas o a Departamentos vecinos. Así se ha dado esa interesantísima migración espontánea de los naturales de Conima al valle de Tambopata; y así se ha praducido el descolgamiento de varias decenas de miles de indígenas $(40,000$ ? 50,000?) del altiplano y la hoya del Titicaca sobre la ciudad de Arequipa. Paralelamente, existe un flujo constante de migración nativa desde log departamentos de Pasco, Huánuco, Ancash, etc., sobre la capital de la República. Expresión visible de este fenómeno es la formación de las "bariadas" populares en casi todas las ciudades importantes del país, en los cuales predomina el elemento indígena.

Hay que advertir que en estas migraciones no influye solamente la presión demográfica. Tiene también su parte un factor económico: la necesidad de buscar salarios más remunerativos que los muy reducidos y hasta miserables que se pagan en la sierra. $Y$ recientemente ha mediado otro factor eventual: la prolongada sequía que agotó los pastos y malogró las cosechas agrícolas en el Departamento de Puno, originando fuerte mortandad de ganados y llevando el hambre a los hogares.

Todos estos fenómenos de orden natural y sociológico han de ser tomados en cuenta por el Poder Público y por la iniciativa privada para contrarrestar sus efectos $y$ para adoptar medidas de previsión a fin de que la clase indígena campesina no se pauperice más de lo que está y a fin 
también de que las tensiones sociales no suban de punto por causa de lo extrema miseria de estos desalojados sociales. El remedio que consiste en la colonización de "Tambopata" puede ser un buen remedio; pero se queda corto. ¿La irrigación del altiplano? Cabe imaginar qué enorme emporio de riqueza podría ser con riego artificial esa zona cubierta hoy casi íntegramente de pajonales o pastos silvestres para la cría de ganado. Pero según opiniones autorizadas, no es factible pensar en una irrigación general de la vasta llanura; pues aunque en ella circulan ríos copiosos como el Ramis, la falta de desniveles y la superficialidad de los cauces fluviales impe. dirían el fácil flujo de aguas en los canales y originarían un gran riesgc de inurdaciones, que hoy mismo se produce cuando los ríos aumentan sus caudales. Esto no quita que, en determinadas zonas del altiplano, en especial las próximas a la cordillera, se dén condiciones propicias para obras de regadío. Sin embargo, no está formada aun en esta dirección la conciencia económica del hacendado; que en general prefiere su fácil condición actual de ganadero. Si el sistema de irrigaciones no es factible, otros serán, pues, los remedios que las entidades pertinentes hayan de buscar para acudir en auxilio del campesino indígena: mejoramiento de los riegos en las campiñas actuales, regadíos de eriazos, expropiación de latifundios no industrializados, irrigaciones nuevas, fomento de las cooperativas agrícolas, etc Tema es éste que excede los límites de nuestra ponencia.

Poco es lo que podemos decir de los grupos indígenas de la selva, tanto pcrque, en rigor, no son aún suficientemente conocidos ni están incorporados a la civilización sino en mínimas medidas, como porque los escasos contactos que el país mantiene con ellos debido en buena parte a la impenetrabilidad de su "habitat", no han permitido infundirles una verdadera conciencia de nacionalidad. Socialmente, no constituyen, pues, una clase; ni siquiera un estrato en el sentido de capa social situada encima o debajo de otras pero vinculadas a ellas. Forman un mundo aparte con su reino propio: el bosque; y con sus propios gobiernos tribales ajenos a la subordinación de toda otra autoridad. Excepcionalmente, en las vecindades de las ciudades y puertos fluviales que en esa zona de Oriente existen establecidos por exigencias militares, por obra de los misioneros o por iniciativa de los viejos explotadores del "caucho", se cuentan agrupaciones sedentarias de aborígenes de varias tribus pacíficas que alternan ya con los pobladores blancos, colaboran con ellos en trabajos agrícolas, en menesteres de transporte o como guías en los viajes, y gustan sobremanera del comercio de baratijas. Pero, en general, esos indígenas llevan una existencia nómada, a veces con rasgos de ferocidad y belicismo. Sociológicamente hablando, el aborigen de la selva es todavía para el Perú un reducto demográfico por captar y asimilar. Mucho es lo que han hecho en favor de esta empresa, cada uno en su ramo, los miembros del ejército que mantienen guarniciones en diversos lugares de frontera (aunque en verdad ha faltado un plano orgánico de colonización militar), las Ordenes y Congregaciones religiosas que tienen a su cargo las misiones católicas y los expedicionarios privados que desde largos años atras han penetrado en la selva para explotar el caucho, las maderas, la quina, el quebracho $y$ otros productos característicos de la región. En años recientes han sido 
establecidas también misiones protestantes, comisiones científicas dedicadas a estudios antropológicos y lingüísticos y capitalistas extranjeros que trabajan a base de grandes concesiones de terrenos con la mira. de explotarlas agrícolamente. Pero, en realidad, la promoción de estas tierras está en su comienzo. Entre tanto, el hombre de la selva es un ser primitivo, de vida al natural, de ínfimo nivel humano en punto a educación, alimentación y sociabilidad, con mitos religiosos paganos y carente aún de un verdadero sentimiento nacionalista.

Como ha ocurrido en todos los países, en el Perú el descrrollo industrial está matando la artesanía. Las actividades artesanales de carácter artístico que florecieron en la Colonia y aun durante buena parte del siglo pasado (cerámica, tejido, orfebrería de plata), se mantienen relativamente en pie debido al aprecio que el turista hace de esos productos típicos, y el fomento que han prestado los gobiemos y organismos internacionales $\alpha$ los artistas nativos para lograr la perduración de lo autóctono, la estilización de las formas y una producción en escala comercial. Pero la mayor parte de los oficios útiles manuales, como la zapatería, la herrería, la carpintería, la tipografía, etc., van quedando relegados a las ciudades de Provincia. En la Capital y ciudades industrializadas, la producción en serie transforma día a día a los antiguos artesanos en obreros, como ocurre con los talleres mecanizados de confección de ropas, de platería vaciada y de la gran imprenta; y con las fábricas de calzado, de tejidos, de muebles, de alfombras, de herrajes y verjas, etc. La figura del "maestro" artesano se hace de vez en vez más rara. Pocos son los oficios de artesanía que conservan entre nosotros su peculiar característica de actividad libre o autónomá como los de joyería, hojalatería, ebanistería de talla, talabartería y confección de riendas y monturas; pero, en general el propio artesano prefiere económicamente incorporarse a la gran empresa para ejercer su actividad como obrero especializado, según puede verse con los albañiles, pintores de brocha, gasfiteros, mecánicos, etc.

La pequeña artesanía ejercitada entre nosotros se ha caracterizado siempre por sus modestos recursos económicos próximos a la estrechez. Por lo general, el artesano dispone de un capital propio muy reducido; y frecuentemente para comprar sus materiales solo hace uso del crédito, avalado por su acrisolada honradez. Rara vez, pues, nuestros artesanos han llegado a escalar los estratos sociales medios: son del pueblo y se sienten hijos del pueblo. Poseen una mentalidad sana $y$ noble, sin resentimientos sociales ni temperamento agresivo; gustan de su independencia; sus familias son constituídas por lo general regularmente; y están desprovistos de todo sentido de previsión $y$ de toda protección en materia de seguridad social. Viven al día y casi nunca dejan nada detrás de sí. Es este, sin duda uno de los estratos más olvidados en el articulado de las leyes sociales.

En cuanto a la clase obrera, la hemos distinguido en urbana y rural. Sus variedades urbanas son múltiples: desde el obrero de fábrica, sindicalizado y consciente, hasta el obrero ambulante $y$ sin ocupación fija, pasando por los diversos escalones de técnicos especializados, obreros califi- 
cados, obreros comunes, obreros auxiliares, aprendices, obreros de servicios públicos $y$ de tansporte, obreros a destajo, domésticos, etc.

En general, la clase obrera disfruta en el Perú de una avanzada legislación social, tanto en orden a las condiciones de trabajo comó en materia de seguridad y previsión; si bien en este último aspecto no siempre los avances responden $\alpha$ un riguroso concepto técnico-matemático y $\alpha$ planes generales preestablecidos, sino a criterios políticos o circunstanciales. Bajo la gran empresa, y también en la mediana, la sindicalización obrera se ha extendido con notable profusión $\mathrm{Y}$ ha servido, sin duda, para alcanzar mejoras salariales $y$ de otra especie, $y$ para divulgar el emplèo de los pactos colectivos de trabajo. Sin embargo, el sindicato no ha madurado todavía. No siempre los dirigentes sindicales saben sustraerse al influjo de corrientes foráneas o de tendencias de partido, y $\alpha$ vecés el sindicato va a la demagogia, aun sin el beneplácito de la mayoría. En general, los tipos de salarios en la Capital de la República alcanzan niveles más razonables $y$ equitativos que en Provincias, donde la pobreza de los ambientes locales impone jornales pobres y con trecuencia deficientísimos. Sin embargo, puede afirmarse que aún nuestros promedios salariales no representan el justo salario familiar de la escuela social cristiana " comprendidos la educación de los hijos, el esparcimiento honesto y el prudente ahorro para contingencias futuras. De otro lado, hay que reconocer que, $\alpha$ la hora de sopesar la equivalencia en el intercambio de prestaciones, hay aspectos en que el obrero suele quedar en falta respecto del patrono: la "hora-hombre" del obrero europeo o americano tiene mayor contenido de trabajo y de eficiencia que lá de nuestro obrero. Entre nosotros menudean los ejemplos de trabajo a desgano, falta de diligencia y perfección, escaso. sentido de responsabilidad, impuntualidad frecuente. No siempre, sin embargo, estos fenómenos entran en la esfera de la imputabilidad moral del individuo: acusan en unos casos deficiencias o vicios de educación y de formación espiritual; son resultado, en otros, de causas físicas como la mala nutrición; pero provienen también de las tensiones sociales con los dirigentes de las empresas o de nocivas propagandas que envenenan el ánimo de los trabajadores incautos. Males son éstos que urge extirpar para dar a las relaciones entre los sujetos humanos de la producción ese carácter de armonía fecunda en que reposa el bienestar común. $Y$ esto sólo es obtenible con el doble concurso de voluntades de obreros y empleadores.

Entre los obreros de la pequeña industria hay gran variedad de situaciones: más favorables unas veces que las reinantes en la gran empresa. Y rayanas otras en la miseria. $Y$ es que mientras en determinadas industrias pequeñas la proximidad del dueño a su personal obrero lo pone en contacto con las necesidades y problemas de éste último y le da margen $\alpha$ ejercitar sus cualidades de hombre comprensivo $Y$ bueno; en otros negocios industriales lo exiguo del capital, la falta de mecanización suficiente o la competencia de precios determina escalas salariales exiguas $\mathrm{y}$ aun injustas.

Mucho más difícil es la posición del obrero ambulante sin ocupación fija, que se gana la vida en los más diversos menesteres: hoy como aya. 
dante de albañilería, mañana como mozo de cuerda en mercados y muelles $y$ otras veces, eventualmente, en la construcción de caminos $u$ otros servicios de obras públicas. Frecuentes intervalos de desocupación suceden a los períodos de trabajo de estos míseros obreros, cuyas familias se debaten en ignorados dramas de miseria. No hay para ellos tampoco, en la mayoría de los casos, prestación de auxilios ni previsión de riesgos en casos de enfermedad, invalidez, etc. La causa fundamental de esta miserable condición suele ser la ignorancia de un oficio definido, el mínimo nivel intelectual, $\mathrm{y}$, por ende, la ausencia de una voluntad disciplinada y cons. ciente capaz de superar las circunstancias adversas de la vida. Son, ésos, proletarios en la cabal extensión del término.

Para la regulación de las reclamaciones obreras sobre casos concretos acaecidos o sobre mala aplicación de las leyes, hace falta una legislación bien estudiada e imparcial. La labor que en este particular ejercita el Ministerio de Trabajo se resiente de graves defectos que redundan en desprestigio del principio de autoridad, $y$ sienton una abigarrada jurisprudencia en cuyos intricados vericuetos se pierde la fijeza de la norma jurídica.

Entre las variedades de obreros rurales, la mós importante es, sin duda, la del obrero de minas. Y cabe distinguir en esta especialidad a aquellos que trabajan en las grandes empresas, de los que prestan sus servicios a la pequeña minería. Los primeros son braceros a tiempo completo, que residen a firme con sus familias en las plantas de beneficio utilizando las viviendas que les proporcionan las compañías. Están por lo general sindicalizados y sus condiciones de trabajo son más o menos análogas a las de los obreros de la gran industria en las ciudades. La principal diferencia respecto a éstos es que los de minas corren mayores riesgos en cuanto a accidentes $y$ a la probabilidad de contraer enfermedades profesionales (neumoconiosis y otras); por lo cual se impone una supervigilancia extrema en el uso de sistemas $y$ aparatos de preservación $y$ seguridad.

La pequeña minería trabaja, por lo regular, con obreros indígenas, que suelen alternar las tareas de las minas con las suyas propias de índole agrícola en las parcialidades y ayllus. Ira remuneración de este tipo de obrero es, por cierto. muy inferior a la del bracero de la gan empresa, corriendo parejas este aspecto con su menor preparación para el trabajo, su mós bajo nivel intelectual y el carácter precario de su tarea.

Cabe cerrar este capítulo con la mención de otro estrato sociall, el más desvalido de todos; el de las gentes sin ocupación y sin posibilidades de tenerla, por razón de ancianidad, de enfermedad, de desadaptación social, o de desempleo: y el de aquellas que en ocupaciones eventuales $y$ mínimas o por causa de debilidad física perciben salarios o propinas de miseria, sustancialmente insuficientes para el sustento suyo y de sus familias. No incluímos en estos grupos a los individuos sean ancianos o enfermos, que viven habitualmente bajo el techo $\mathrm{y}$ al amparo de sus familiares. Nos referimos sólo a quienes como jefes de familia o como personas aisladas tienen exclusivamente sobre sus hombros la responsabilidad de su 
VII.-La llamada clase media:- su evolución en el Perú. - Los grupos muy cerca de nosotros, en las barriadas populares, y en los "callejones" y conventillos de la ciudad, donde el modo de vida es visiblemente infrahumano. Todos esos elementos constituyen la verdadera clase menesterosa, por la cual han de velar las instituciones de asistencia del Estado, y en cuyo favor ha de cumplir sus deberes la caridad cristiana.

VII-La llamada clase media:- su evolución en el Perú.- Los grupos de la clase media en la sociedad actual: Profesiones liberales.- En caso de los intelectuales. - Rentistas y pequeños propietarios. - Industriales y comerciantes. - Empleados particulares y burócratas. - Apostillas generales sobre el sector medio.

Hasta hace algunas décadas puede decirse que no existía en el Perú una verdadera clase media. Nuestra población se agrupaba fundamentalmente en dos campos: el del grupo dirigente y rico; $y$ el del pueblo modesto y pobre. Ciertos grupos sociales que parecían intermedios, como el de los burócratas y empleados, no poseían importancia numérica y carecían, sobre todo, de una verdadera personalidad de clase, constituyendo más bien algo así como apéndices parasitarios de la clase dominante. Esto, cuando su precaria econcmía no los desviaba hacia el lado de los estratos populares.

Pero surgieron factores que han hecho variar el panorama: el crecimiento demográfico, el proceso de industrialización, la modernización de la empresa, el desarrollo del comercio, el aumento de los servicios de la administración pública, la multiplicación de los transportes, constituyen hechos sociales que han traido como consecuencia la necesidad de incluir en esas nuevas ramas de labores una cifra de gente mucho mayor que la de antes y con un cierto nivel de educación y preparación intelectual. Se abría un campo muy vasto para poblar la clase media.

Ocupan en ésta el primer plano las profesiones liberales, cuyas asociaciones gremiales han adquirido apreciable fuerza e influencia en los últimos tiempos, bien sea en el aspecto de la política profesional bien en el de la colaboración técnica con el Estado para abordar problemas de interés púllico. Se echa de menos, sin embargo, en la Universidad, fuente institucional de esta clase de profesiones, una mós definida decisión orientadora de los estudios hacia disciplinas vinculadas a los conceptos de productividad y técnica económica, a fin de que la juventud se capacite en este nuevo género de profesiones-técnicas. El exceso de abogados conduce a la proliferación estéril de los pólíticos con mengua de trabajo productivo: $\mathrm{y}$ los estudios universitarios de las Humanidades deberían quedar reservados a los estudiantes de "élite" con definida vocación filosófica o literaria.

No significan estos juicios, en modo alguno, una apreciación peyorativa del intelectualismo, ni una preferencia en favor de los aspectos positivistas de la enseñanza. Enuncian, simplemente, la necesidad de un 
equilibrio y de una coordinación armónica entre las expresiones espirituales y materiales de la actividad social. Unas $y$ otras se ayudan e integran recíprocamente en el trabajo de forja del bien común. Precisamente, desequilibrio, la ruptura de proporciones entre las profesiones liberales, trae consigo los fenómenos de plétora de individuos en unas y de escasez en otras, que provocan tensiones sociales $y$ perturban $o$ estancan el ritmo del progreso colectivo. El ejemplo lo tenemos en nuestra propia realidad. En el Perú nos falfan técnicos: nuestros economistas se cuentan con los dedos de la mano. San Marcos hace contadores pero no economistas. No existe suficiente variedad de ingenieros industriales: en más de un caso, se hace preciso viajar al extranjero para adquirir determinadas especialidades aún no implantadas entre nosotros. En cambio, la abundancia de abogados obliga a muchos de estos profesionales a buscar un medio de vida suplementario en la burocracia: y esto deprime la jerarquía de la profesión e incuba el resentimiento. En la profesión médica, la falta de varias Facultades de Medicina en Provincias centralizó hace poco los estudios en la Capital de la República y ha sido aspiración generalizada en los recién graduados la de quedarse en lima. Fste fenómeno de irracional centralización no sólo se produce en desmedro de la asistencia facultativa en gran número de pueblos provincianos, sino que origina un intenso malestar social. Hay abogados y médicos que, por razones de familia, de vinculaciones $y$ de talento triunfan on el ejercicio profesional $y$ de hecho se incorporan en los estratos superiores de la sociedad a que sus clientes pertenecen. Aunque profesen lealtad a su clase $y$ se mantengan en su seno como profesionales, emigran de ella en la social y pasan a formar parte de una escala más alta. La reacción automática de los que quedan, de aquellos que, quizás con igualdad de talento, no tuvieron la misma suerte o las mismas oportunidades es una reacción de amargor. Se les crea un complejo psicológico que quiebra la solidaridad entre colegas y suscita Iuchas intestinas. $Y$ puede llegarse a casos de proletarización profesional.

Merece mención aparte el grupo de los intelectuales y artistas, que aunque no pocas veces sin título académico o universitario, representan el pensamiento y modo de sentir de su generación y se asimilan a los profesionales en cuanto a su actividad liberal y apego a labores del espíritu. Pertenecientes a ln capa media de la saciedad por no ser, en general, poseedores de fortuna, reivindican para sí la aristocracia del talento $y$ están llamados, realmente desde su plano de ideólogos, a participar en la conducción de su pueblo. Forman parte en este sentido de la clase dirigente. En los últimos tiempos, las expresiones de arte no se han limitado a casos de producción individual, sino que van adoptando la forma más significativa socialmente de ensayos colectivos (teatro, danza). Desde el libro $y$ el periódico, la opinión del intelectual gana influencia cada día en la orientación de la política, de las instituciones $y$ de las reformas. $\bar{A}$ nadie puede ocultarse la importancia adquirida en los últimos veinte años por el periodismo en el Perú. Y surge, como consecuencia, la necesidad de que se afirme en ese grupo social, con convicción severa, el sentido de la responsabilidad. La percepción de que es muy grave y tendrá trascenden- 
cia histórica la misión que han de cumplir. Pero en el campo económico, la clase intelectual no tiene aún ambiente suficiente en el Perú. Son pocos los que pueden pagar bien al artista. El libro alcanza difusión reducida y las ediciones populares dejan un margen estrecho de utilidad. Está aún esta clase en la etapa inicial de su afirmación económica.

Cabe también catalogar entre las capas medias de la sociedad a los pequeños rentistas que viven de los frutos de sus bienes inmobiliarios, de sus valores bursátiles o de sus ahorros pecuniarios; así como a los pequeños propietarios que trabajan por sí sus tierras y extraen de ellas lo necesario para alcanzar la "dorada medianía" de que hablaba Fray Luls de León.

Uno de los sectores que más se ha incrementado en los últimos años en el Perú, dentro de la ubicación de las capas medias, es el del mediano comerciante que prosperó en su giro durante épocas de bonanza, y el del mediano industrial que implantó con visión una industria útil y ha logrado su florecimiento. En este orden de actividades se advierte ya un grupo social bastante nutrido, con espíritu de empresa, don de trabajo y visible bienestar económico. El inmigrante extranjero o sus descendientes son el núcleo central de este grupo; pero la integran también meritorios elementos calificados de la burguesía nacional, que han amasado honestamente con su esfuerzo, sus modestos pero saneados patrimonios. Infortunadamente, hay también posiciones de esta clase que se han labrado a costa de menos limpios procederes: pingües contratos de obras del Estado, comisiones ilícitas, nepótico disfrute de prebendas fiscales. Condenables ejemplos de impunidad.

El sector de los empleados particulares admite una gama muy variada en punto a holgura económica: desde los altos funcionarios técnicos y administrativos de la gran empresa, el piloto aéreo y el administrador de hacienda, hasta el modesto empleado de mostrador, el experto en contabilidad, el vendedor comisionista, la secretaria-taquígrafa, la enfermera de clínica, el regente de imprenta, etc. En general, los funcionarios y técnicos de empresa y los altos empleados estón bien remunerados, sobre todo si son extranjeros y perciben sus sueldos en divisas oro. Pero en los empleos corrientes o secundarios, junto a casos de justa remuneración, los hay en que la paga es floja y aun deficiente, sin que exista muchas veces correspondencia entre el volumen de las utilidades del principal o de la empresa y la escala de sueldos de sus dependientes. Lo más inequitativo de estas situaciones de deficiencia salarial es que el empleado está obligado por obra del convencionalismo social, a arrastrar, en lo que concierne a vestido y habitación, una apariencia de vida que se acerca más a la del acaudalado que a la del obrero. En este sector, lo mismo que en el obrero. la acción sindical se presenta especialmente intensa y en veces extremosa, con casos de repercusión en la economía general.

La clase burocrática alcanza en el Perú un volumen considerable. Publicaciones recientes certifican que alrededor del 80\% del Presupuesto nacional se dedica al pago de haberes y bonificaciones; de donde se infiere que la mayor parte de los recursos fiscales tienen un destino vegetativo 
- de consumo, y que apenas un $20 \%$ está destinado a gastos materiales - fines reproductivos. Influye sin duda en este fenómeno el hecho de qua las actividades privadas de la producción y de la industria no alcanzan a absorber a la totalidad de las gentes que buscan trabajo. Existe también entre nosotros una vieja tradición de empleomanía fiscal, que no es extraña al hábito del ocio improductivo y a la creencia en el providencialismo del Estado. Pero actúa también decisivamente en la hipertrofia de este ramo, la influencia del factor político, que ha convertido a la burocracia fiscal en mercado de favores, refugio de prebendas y cebo de interesadas adhesiones. Según este criterio, no se toman en cuenta las prendas personales de capacidad y honorabilidad, ni se compulsa el grado de necesidad de la plaza: ésta, incluso. llega a inventarse cuando el presupuesto no la consigna, y el ahijado político ingresa como "contratado". De aquí resulta que la Administración Pública va perdiendo sus atributos de eficiencia y responsabilidad. Se ha llegado, así, a poder distinguir en nuestro mundo burocrático dos sectores perfectamente definidos: la burocracia de carrera en la cual hay muchos casos ejemplares de circunspección y sentido del deber, $y$ que es detenida con frecuencia en sus legítimos ascensos por la interposición en altos cargos de los nuevos burócratas; y la burocracia advenediza, sin calidades éticas ni devoción por su tarea. Suscítanse por estas causas explicables tensiones internas que dislocan la solidaridad de clase $y$ amenguan el prestigio de su función.

En la capa burocrática auténtica inclúyense dos grupos de alta respetabilidad: los maestros, que no sólo por su condición de profesionales, sino por la misión social delicadísima que les está confiada, merecen toda la vigilante atención $y$ todos los estímulos por parte del Estado; y la oficialidad de los Institutos Armados, a quienes están confiados el orden social interno y la defensa exterior. Los soldados conscriptos temporales, no pueden, en rigor, ser incluídos en el grupo burocrático: son ciudadanos que pertenecen al estrato social que, por razón de sus actividades civiles, les corresponda en su ciudad, en su pueblo o en su zona rural.

Hablando en tesis general, los haberes básicos de los empleados públicos son bajos, sobre todo en lo que atañe a los de pequeña categoría. Hay familias de extracción burocrática, en las escalas ínfimas, cuyo presupuesto es tan sumamente estrecho que van camino de la proletarización. En cambio, en las escalas altas se registran no pocos casos de excepción en los que por razón de artificiales elevaciones de grado o por acumulación de funciones, (que fueron recientemente denunciadas) se descubren haberes de monto sorprendente e ilegítimo.

Uno de los problemas más serios por remediar en la clase burocrática es el de su falta de preparación técnica, derivado en parte de otro problema: la ausencia de un sistema de planificación administrativa y de métodos modernos de fichas $y$ clasificación. En rigor, no se ha previsto qué funciones corresponden $\alpha$ cada puesto, ni qué labores incumben $\alpha$ cada empleado; $y$, como consecuencia, no se sabe qué requisito de capacidad ha de exigirse en cada caso a los postulantes a empleos públicos. $\mathbf{E l}$ resultado fluye: desorden, inespecificación de obligaciones, fluidez cons- 
tante en su labor propia, ausencia de tradición o historia en el proceso de los asuntos, deficiente o mala organización del archivo. Como esta situación no puede perdurar y ya el Estado parece haber confiado a una misión técnica el intento de una ordenación en esta materia, cabe avizorar las dificultades con que, de inmediato, se va a tropezar frente a la ignorancia o deficiencias de los actuales empleados. $O$ han de iniciarse cursos severos de capacitación, o ha de ser ésta la oportunidad de conservar en al escalafón burocrático sólo a aquellos servidores que estén en condiciones de asumir las responsabilidades exigidas a su cargo.

Tócanos, completando este resumen sobre las capas medias de nuesm tra sociedad, hacer las siguientes apostillas finales:

a) El crecimiento de la clase media en el Perú es un indicio favo. rable en la evolución de su proceso social. Revela que las profundas desigualdades de los estratos extremos de la comunidad, se van colmando con elementos intermedios surgidos del pueblo mismo; y que los niveles socialos y económicos van mejorando.

b) Existe ya cierta corriente de circulación sccial, de movilidad de una clase a otra. Cada vez es mós frecuente el caso del hijo de obreros que sigue cursos por correspondencia o estudia en la Universidad, o que ha llegado a ser profesional. La adolescente del suburbio estudia taquigrafía y aprende lenguas extranjeras para ser empleada. Se dan también, a la inversa, casos de empleados particulares o de burócratas que no pudiendo brindar a sus hijos la educación secundaria en un colegio particular, los envían a una escuela técnica para hacerlos mecánicos de aviones - técnicos especializados en alguna rama de la industria; con lo cual, aunque quizós dentro de un erróneo convencionalismo burgués, desmejoran de situación social; aseguran en cambio de un modo más efectivo su preparación trente a la vida y su porvenir económico.

c) Adviértese en las capas medias un evidente afán de cultura y un impulso de superación. El periódico les lleva diariamente la noticia Y el comentario de actualidad. La mayor afluencia a las bibliotecas públicas y municipales corresponde a las clases media $y$ obrera. De ellas salen también los aspirantes a profesiones liberales. El cine es el espectáculo de la clase media. El deseo de superación social se trasluce, en la mujer, en ese fenómeno de mimetismo que la mueve a imitar a la clase más elevada en la moda, en los juegos, en el estilo de las fiestas; y se revela en el hombre, en su creciente intervención en la política. Hoy en día la clase media, a través de los partidos jóvenes, intenta reivindicar para sí la conducción del Estado.

d) Hay sectores de la clase media que van perdiendo el respeto al principio de autoridad. Esbózase el designio de entrentar al poder del Estado el poder del Sindicato; y asoma la tendencia de imponer desde la arena gremial, las orientaciones sociales de la legislación. La crisis de autoridad se va trocando en transición de autoridad. 
VIII-Las clases como conjunto social. - Estimaciones sobre la proporción numérica de las clases.- Actitudes recíprocas que éstas adoptom o mantienen dentro del conjunto social:- Lucha y solidaridad de clases.

Los diversos grupos sociales descritos hasta aquí no viven aislados y en la ignorancia unos de otros: estón ligados entre sí por la geografía y el contacto humano; y ese contacto provoca su conocimiento recíproco, con acciones $y$ reacciones de solidaridad o de pugna según que entre ellos exista coincidencia o disparidad de conceptos, posiciones e intereses. Nace la dinámica social.

Dos elementos capitales de ese dinamismo son el aporte numérico do personal humano que cada grupo lleva al conjunto social, y la relación de ese aporte con los medios de producción. Cuando hay correlación equilibrada entre la calidad personal del grupo y la posición funcional que ocupa en el conjunto, $y$ entre el volumen del grupo $y$ el volumen de sus recursos, no hay tensiones ni problemas en la comunidad. Pero cualquier desequilibrio en algunas de estas proporciones genera la ineficacia, el atraso y la lucha.

La carencia de datos estadísticos recientes y científicos no nos permite dar guarismos sobre la exacta distribución de la población del Pérú por clases sociales. Podríamos, en cambio, acudir a criterios que nos diesen una idea aproximativa de la realidad, enunciando, por ejemplo, la proporción más o menos conocida entre la tenencia de la tierra y el volumen de la población en determinadas zonas del territorio nacional.

Así, en la región de la costa, las propiedades registradas en las dependencias del Ministerio de de Agricultura con extensión mayor de 100 hectáreas cada una, representan alrededor del $75 \%$ del área cultivada; al paso que la pequeña y mediana propiejdad suma escasamente un $25 \%$ del área total. Lo cual quiere decir que en la costa domina el régimen de la gran propiedad; si bien es de advertir que ésta se encuentra en buena parte industrializada con beneficio del volumen de producción. El problema consiste allí en que los frutos industriales se reviertan equitativamente entre los factores que contribuyeron a obtenerlos.

En el Departamento de Puno, se, calcula que las tierras de los comuneros de los ayllus y las de los pequeños propietarios individuales, suman un 33\% del área total del altiplano; en tanto que el dominio de los propietarios de las haciendas se extiende a un 67\%. Como estos propietarios ceden a sus colonos el uso precario de pärcelas que sumarían aproximadamente un $19 \%$ del área de las haciendas, los grandes propietarios mantienen para sí la explotación del $48 \%$ de esa órea; $y$ el área trabajada por pequeños agricultores e indígenas de los ayllus sube al $52 \%$. Ahora bien: los propietarios de haciendas representan menos del $0.5 \%$ de la población rural del altiplano: todo el resto de esa población (más del $99 \%$ ) 
trabaja el $52 \%$ de la tierra. La conclusión no es dudosa: en el Perú hary una mala distribución de la tierra (7).

Si revisamos el "Vademecum de Inversionistas", editado por el Banco de Crédito del Perú, podemos, igualmente, llegar a la deducción de que una gran parte del volumen de capitales invertidos en el país está concentrado en un reducido número de manos.

Vistas las cosas desde otro ángulo, el volumen de trabajo que el Perú puede rendir para el fenómeno de la producción, es mucho menor que el que aporta la generalidad de los países que cuentan con una población igual a la suya, pero homogénea y civilizada; por la sencilla razón de que la mitad o más de la mitad de nuestra población pertenece a la raza aborígen, cuyo rendimiento de trabajo en la agricultura es mínimo en tiempo y calidad, debido a sus métodos lentos y primitivos de explotación y a sus deficiencias de capital, y cuya capacidad de rendimiento industrial como obrero está limitada por sus condiciones de incultura, de "habitat" y de falta de preparación técnica. Claro es que estas calidades negativas no son absolutas, pues ya nuestro aborígen va despertando visiblemente de su letargo y muestra ejemplos de notable pro'greso; pero en general, hay que comenzar por educar y capacitar al indio e incorporarlo a las modalidades de la vida civilizada para que su aporte de trabajo pueda ayudarnos a igualar con otros países el ritmo de nuestra dinámica soctal.

El ideal de una sociedad consistiría en que sus clases trabajadoras estuvieran solidariamente unidas por el bien general. Más la propia desigualdad entre ellas es el germen de diferencias que es menester rducir y concordar para que el objetivo de la armonía sea logrado. Intentemos examinar cuthes son en nuestro medio las actitudes recíprocas de las clases y en qué grado se advierte en ellas interés por las demás, espíritu de lucha o voluntad de coordinaión.

En general, la clase dominante se preocupa poco, desde un punto de vista social propiamente dicho, de la condición y la suerte de las demás clases. Ha preferido dejar que éstas sigan naturalmente su proceso evolutivo. Ella ha sido una espectadora. Se ha limitado a cumplir la ley cuando ésta le ha impuesto obligaciones sociales. Solo excepcionalmente, empresas comprensivas se han adelantado a la ley o han mejorado las condiciones que ésta otorga a los dependientes. Pero, eso sí, en el caso particular, frente al llamado concreto de la desgracia o de la miseria, acude con emoción y con generosidad. Pruebas de ello tenemos en el éxito obtenido por el Padre Alcocer en su "Banco de Dios" y en el fervor de las damas y caballeros que acuden a la "Misión de barriadas". Los grandes industriales se resisten al diálogo con sus dependientes y obreros salvo cuando su producción peligra. En general, no revelan haber comprendido que una asociación espiritual entre ellos, por encima aún de cualquier asociación material o baratijas de ganancias : puede traerles satisfacción e incrementar la producción y sus ingresos. El capital de inversión y la banca privada

(7) Datos del Ing. Sr. Augusto. 
actúan con un sentido demasiado exclusivo de lucro si se atiende a los fines de una sociedad cristiana en la que los valores materiales solo cuentan en cierta escala y tienen mayor peso los valores de la ayuda mutua, la equidad discreta y la paz de los ánimos. Falta, en suma en los grupos dominantes, una formación intelectual más integralmente humana, una intuición moral más profunda de la enseñanza y el ejemplo de Cristo. También, en ellos, el problema es de educación: de estudio serio del proceso social del mundo, y de adquisición de una sensibilidad adecuada a la época. Definitivamente deben dejar de vivir en el pasado y pensar a la manera del pasado.

Esta cuestión de la sensibilidad es sumamente importante. Si intentáramos definirla, diríamos que es la adivinación del alma ajena, la previsión de las reacciones de los demás, el afán de no lastimar todo 1 que hay de respetable: y doloroso en la intimidad de nuestros prójimos. La sensibilidad tiene algo de antena. Por eso estamos seguros de que cuando los hombres de nuestros sectores sociales elevados hayan aprendido el secreto de esa sensibilidad, se acercarán inmensamente al desvalido y suprimirán de su vida $y$ de sus costumbres muchas de esas notas externas que, aun sin ellos percibirlo, estón indudablemente mal, porque hieren a otros en sus sentimientos $y$ en su pobreza: fiestas fastuosas, lujo desorbitado, banquetes frente al hambre, ceremonias sociales en que se hace frívola exhibición de vanidades. $Y$ todos, en nuestra esfera, habremos de contribuir a esta saludable rectificación de rutinas. Suprimirán los periódicos su página social, que hace profundo daño. Omitiremos los viandantes el gesto de impaciencia trente al mendigo que nos pide una limosna. $Y$ no tendremos a menos sentarnos en el banco de la Parroquia con la frutera de la esquina.

En la clase media, se ha perdido o está a punto de perderse el sentido de la deferencia y de respeto hacia las clases dominantes. Para ella y para el pueblo, el ascendiente moral del grupo aristocrático está en declinación; $y$ aunque los viejos apellidos mantienen una aureola de prestigio inocultable, lo cierto es que cada vez va siendo más raro el caso de familias cuya influencia cobre proyección nacional. El ascenso de posiciones en los estratos medios crea en sus miembros la aspiración a un trato de igualdad, del cual difícilmente exceptúan al poderoso. No obstante, el individuo medio suele sentirse por encima de las capas populares $y$ vive a cierta distancia de sus gentes. Como fuerza nueva es que, y con vigor de juventud, aspira el grupo medio a ganar posiciones en la vida nacional. Después de haber alcanzado acceso a la propiedad, comienza ahora a disputarle al grupo dominante su viejo monopolio político. Poseedor de un sentido más realista y sencillo de las cosas, más próximo a la verdad de la tierra, más seguro del suelo que pisa, la clase media estaría llamada $\alpha$ representar en nuestra estructura social una orientación de serena maestra democrática, un útil elemento de síntesis entre la gandilocuencia décimonónica de nuestros repúblicos, la holgada solvencia de nuestros potentados y la eficacia popular de nuestros montoneros.

En la esfera individual se registran manifestaciones que revisten interés desde el punto de vista de la actitud de unas clases respecto de otras. 
Asi, el alto empleado suele sentirse más identificado con los intereses de su principal que con los de sus compañeros de oficina; el burócratu fiscal muestra demasiado obsecuencia con el hombre de alta situación; el obrero calificado desdeña al empleado modesto porque a pesar de disponer éste de menores ingresos, tiene que mantener una apariencia económica mejor que la suya; el pequeño industrial, en la jefatura de su fábrica, llega: en vecess a ser más rudo con su personal de trabajadores que el gran gerente de empresa, debido al contacto diario que con ellos mantiene; pero ese contacto le permite conocer mejor sus problemas y necesidades, y en la práctica, la dureza se resuelve en un acercamiento más activo y fructífero.

En el obrero la mentalidad es propensa al resentimiento antes que a la cordialidad respecto de los principales. Mayor resentimiento a medida: que la incomprensión del patrón es más aguda o que las tensiones sociales son mayores por causas privativas de cada empresa. Hemos dicho resentimiento y no odio porque en rigor de verdad, no creemos que esta pasión. haya anidado íntimamente en el corazón de nuestros trabajadores. Sin embargo, recientes conflictos deben ponernos sobre aviso: la intemperancia de ambas partes interesadas en una controversia social exacerba los ánimos, fricciona la susceptibilidad, lastima el amor propio, $y$ es fácil entonces que el resentimiento sé convierta en rencor.

No siempre el fenómeno de la lucha de clases supone un resorte: interno de odio ni significa, como en la concepción marxista, una decisión. de destruir radicalmente al capitalismo como clase. Puede significar, simplemente un propósito de ajuste. $Y$ así es entre nosotros. En nuestras huelgas. y conflictos sociales, la lucha tiene esa índole y ese objetivo; ajustar. Llegar a una comprensión. Se lucha por un mejoramiento de condiciones de trabajo. Se protesta contra algo que se considera una injusticia. Se da, en el fondo, por supuesta la necesidad del capital; lo que se intenta es reducirlo a concesiones más benévolas. Mientras estas exigencias enfoquen la defensa del trabajador como persona humana y preserven su dignidad y seguridad, el Derecho admite esa pugna y la regula. Pero el exceso es demagogía. Y en este peligro caerán nuestros sindicatos si, por justas que puedan ser las reclamaciones formuladas, se resisten a llevarlas por los caminos legales y tratan de imponerlas por la fuerza. Un verdadero estado de Derecho no admite esa solución porque desquilcia todo; autoridad, economía y hasta el propio peculio de los reclamantes.

El concepto de solidaridad social se presenta entre nosotros especialmente en el ámbito interno de cada clase, entre sus propios miembros, para defender los fueros de la misma o los derechos de sus componentes. Los miembros de tal o cual grupo económico, se sienten solidarios cuando el Poder Público adopta una medida que les parece lesiva o cuando alguien atropella su estatuto jurídico. La solidaridad gremial interna se manifiesta también en expresiones creadoras o constructivas: asociaciones mutualis tas, cooperativas de vivienda, consorcios de exportación "etc. Pero se da menos veces, en cambio, el caso de manifestaciones de solidaridad exter na, de las clases entre sí, de alianza de grupos sociales de diferentes extracciones para un fin dado. Tenemos, desde luego, el ejemplo de la soli. 
daridad nacional por la que, sobre todo en momentos de crisis, la actitud de las clases converge en la superior unidad de la Patria. Conocemos también el caso de la solidaridad política, en la que, bajo la advocación de un partido o de una coalición electoral, varias clases sociales diversas llevan listas comunes de candidatos. Hemos visto, incluso, episodios de solidaridad inter-gremial en las riesgosas y discutibles huelgas llamadas "do solidaridad", donde sindicatos o gremios extraños al conflicto se solidarizan con la causa del grupo huelguista para reforzar sus demandas. Pero on el Perú echamos de menos otra expresión de solidaridad entre clases, que nos hace falta y que sería especialmente fecunda: la solidaridad frente a la miseria. Esa que debería producirse espontánea, instintivamente, posponiendo cualesquiera distanciamientos recíprocos, afrontando cualesquiera sacrificios, poniendo a contribución todos los recursos, cuando hiere nuestra vista, la vista del hombre rico o mediano, del aristócrata o del plebeyo, del campesino o del comerciante, del médico o del filósofo, el penoso espectáculo de otros hombres de hermanos nuestros en la fe de Cristo, que viven como si no fueran hombres, por debajo de la escala de los hombres, en una especie de mazmorra intelectual, moral y corporal en que no existe ni la sombra de esa luz mental, de ese bagaje cultural, de esa formación ética, de esa dignidad social, de ese mínimo vigor físico que son señeros atributos del hombre que Dios creó. Hacia esa solidaridad integral debemos propender en nuestra sociedad; sólo dentro de esa forma de solidaridad podremos preciarnos de haber logrado una verídica unidad nacional. en la que nadie permanezca excluído de la participación de los bienes materiales y espirituales que son patrimonio común de todos los hombres.

Hay un fenómeno de grave trascendencia que va envolviendo a todas nuestras clases sociales y muy en especial a los estratos elevado y medio en una especie de solidaridad negativa de creciente solidaridad por contaqio, que amenaza minar los fundamentos de toda la estructura social. Nos referimos al cada vez más acentuado decaimiento de la vida familiar y a la prematura emancipación de los hijos de la autoridad paterna. La intimidad conyugal se enfría. La esclavitud de las apariencias sociales impone sacrificios con desmedro de la renta familiar. Una fiebre de alocados desórdenes irrumpe en el espíritu de las generaciones jóvenes, en las que la nota característica es la falta de respeto por todos los valores del pasado. $Y$ esta nueva filosofía sin brújula y sin meta, que abre a la consideración cristiana un filón de inquietudes, le plantea al mismo tiempo apremiante demanda de soluciones.

\section{X.-Las clases como conciencia anímica.- ¿Hay una verdadera conciencia de clase en todos los grupos sociales?}

Ante todo, precisa deslindar el concepto de lo que aquí entendemos por conciencia de clase. No queremos referimos al grado de claridad mental que el miembro de una clase posee y que le permite darse cuenta exacta que él pertenece $\alpha$ es $\alpha$ clase. Esto describe simplemente la conciencia inte- 
lectual del individuo: el así descrito, es un hombre consciente. La conciencia: de clase es algo más. La tiene aquel que, a sabiendas de cuáles son las. características propias de su clase, buenas o malas, favorables o adversas, agradables o duras, las acepta con deliberación para sí y ratifica libremente su adhesión al grupo con vínculo leal y permanente. La conciencia de clase agrega, pues, un elemento de libertad moral. Es la voluntad de elegir su grupo, con halago o con sacrificio, en el humano convivir.

A la luz de esta advertencia previa, sería aventurado afirmar que exista en el Perú una verdadera conciencia de clases, por lo mismo que según venimos viendo en el curso de este trabajo, en nuestro país las clases están todavía en formación, los estratos sociales distan mucho de haberse plasmado definitivamente en lo racial, ni en lo económico, ni en lo cultural. Como en toda la América Latina, en el Perú se da el fenómeno de que tras el antiguo inmovilismo semi-feudal y mutaciones estamentales, sea por la causa de factores técnicos-económicos, sea por obra del mestizaje o por la difusión de Ia cultura van surgiendo así nuevos grupos sociales de rápido dinamismo y de híbrida y elástica plasticidad. Allí donde el hombre rompe las amarras de una clase tradicional todas las posibilidades le están abiertas: el aristócrata se hace industrial o soldado, el lacayo se doctora o se tonsura, el siervo pasa a la burguesía y el militar acaba en terrateniente. Así en nuestra república al amparo de la gratuidad de la enseñanza, el hijo del obrero que obtenga plaza en locales escolares llegará a profesional sin que sea óbice para ello su humilde situación de origen. No es raro el caso de profesional de padre; analfabetos. El aristócrata en falencia tendrá que hacerse burócrata $\mathrm{De}$ un limpia-botas puede surgir un músico genial. El pobre menestral que envía a su hijo a la Uuniversidad no es, precisamente, un modelo de lealtad $\alpha$ su clase. Bajo estas condiciones de ambiente, no se puede exigir la rigidez de una conciencia de clase, porque ello implicaría propiciar el inmovilismo en la estrechez. Ahora, si se toma una clase o grupo social en pleno funcionamiento, el fenómeno se repite: los disidentes de la huelga en el grupo sindical demuestran que su conciencia individual no comparte en ese momento la política de su clase. Es frecuente en el mismo género de ejemplos, el caso de la mujer empleada que muestra resistencia a identificarse con cualquier extremismo gremial. En ambas situaciones, hay pertenencia a una clase, pero hay conciencia de clase. Lejos de ello, se esboza una ruptura.

Pero si bien el fenómeno de la movilidad social atenúa y socava la conciencia de clase, impidiendo que ésta se estabilice, no puede negarse que entre nosotros va surgiendo un cierto orgullo de clase que es un preludio de estabilización. Ese orgullo es, lógicamente, más pronunciado en las clases privilegiadas que, además del poder económico, tienen en favor suyo el factor racial. Se está bien donde se vive bien según el dicho popular; y por eso el privilegiado ama a su clase, tiene conciencia definida de formar parte de un grupo que considera suyo $y$ en el que quiere perdurar.

En las que llamaríamos clases medias no puede afirmarse que haya un espíritu de clase suficientemente exclusivo; porque, por lo general, esas clases tienen un antecedente histórico, una amarra familiar, un recuerdo de otro grupo que es difícil arrancar, del cual no es fácil prescindir. El descen- 
diente de una familia de abolengo venida a menos puede haber necesitado

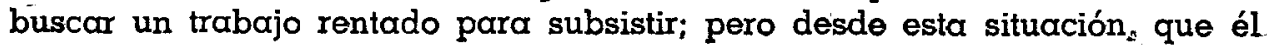
siempre considera eventual, no deja de añorar con nostalgia la cuna y el privilegio. El profesional hijo de obrero respeta el tugurio donde nació. Además, los sectores medios tienen en su propia índole la marca de lo inacabado, de lo que está en proceso, de lo que aún ha de subir; y por eso resulta natural en esos sectores el deseo de identificar sus intereses con los de los grupos mós elevados o de mayor poder económico, a quienes miran como modelos de su papel futuro en el campo social. El mimetismo que antes anotáramos asoma nuevamente en la idiosincracia de la clase media.

En las capas proletarias educadas o conscientes, la aspiración a mejorar es un acicate instintivo; y, por lo mismo, sus individuos se sienten en ellas como aves de paso, sin ninguna conciencia de estabilidad. Sin embargo, la sindicalización trata de fiar el criterio del proletario; de obligarlo a pensar en su clase, a amarla como una víctima, a defenderla como una liberación. La huelga es un instrumento de tijación, que lleva al individuo al trance heroico. $Y$ en esta forma suelen darse casos en que la conciencia de clase arraiga en algún pecho idealista. Puede arraigar también en dirigentes sindicales a quienes su misión de mando o consideraciones de otro orden, retienen en su trinchera. Pero, prócticamente, entre nosotros es muy difícil creer en la generalización de estos casos. Son muchos todavía los que no están preparados. El tipo común de nuestro obrero vegeta en su faena cuotidiana con miras al sustento $\mathrm{y}$ al atractivo gris de su pequeño mundo, sin mayor esperanza de mejora, pero también sin mayor apego a ese ambiente del sindicato que a veces lo presiona y lo cohibé. En su islote de resentimiento, siente en su fuero interno que él saldría de. allí gustosamente si alguien le diera la mano para remediar sus cuitas.

La conciencia de clase se robustece y consolida a medida que la sociedad progresa y se perfecciona. Mientras mejor comprendidos son el valor y la excelencia del trabajo y más respetado es el trabajador en su calidad de persona $y$ en su papel de factor esencial de la producción, el individuo adquiere mayor conciencia de la importancia de su grupo y de la función. social que a él le toca desempeñar en su seno. Entonces sobreviene la conciencia de clase, el sentirse a gusto donde se está. Porque habrá sobrevenido la armonía. Porque, sin perjuicio de la diversidad, cada clase tendrá su propio equilibrio y su propia estabilidad. Porque en cualesquiera do ellas el hombre vivirá como hombre, con libertad sin temor, con holgura sin hambres, con personalidad sin envidias, con un nivel de cultura que le permita el sagrado placer de pensar. $Y$ esto llega, esto puede llegar sin necesidad de lucha por sólo un acto fervoroso de voluntad que dé a los miembros de todas las clases el cristiano sentimiento de la justicia. Entonces será prácticamente indiferente pertenecer a una clase o $\alpha$ otra, porque en todas tendrá realización el ideal de la fraternidad humana. 
X.-La misión y la acción de la Iglesia en el campo de las clases sociales.Cómo puede apreciarse la labor de la Iglesia Peruana en este campo.Doctrina y apostolado social.- Encuesta objetiva sobre si los católicos del Perí tienen un concepto claro de la actitud que les incumbe ante el hecho de las clases sociales.

Si el poder del Estado gobierna la sociedad desde el punto de vista temporal en sus aspectos político-administrativos, a la Iglesia le toca gobernarla con proyección hacia lo eterno, en los aspectos espirituales y morales de la vida religiosa. Dogma y costumbres son los dos temas en los cuales ha de centrar la Iglesia su enseñanza para ilustración de los creyentes. El dogma es la verdad, es la doctrina. Las costumbres dicen relación con la caridad. La enseñanza de la doctrina, de carácter predominantemente intelectual, habla a la razón. La prédica sobre costumbres, que habla más bien al corazón, se dirige a templar en la virtud los resortes de la voluntad. Al conjunto de esta misión le llamamos apostolado social.

Si habemos de auscultar en nuestro ambiente cómo es apreciada a la luz de una crítica culta y sana la labor de la Iglesia en nuestro pueblo, podríamos recoger estas dos impresiones fundamentales: La actividad de la Iglesia no ha sido todo lo afortunado que debiera en su divulgación del mensaje de Cristo, en el propósito de compenetración profunda del significado de este mensaje en la mente de los católicos. La actitud de la Iglesia no ha sido suficientemente eficaz en el campo de la solidaridad social, para el efecto de infundir en las costumbres ese sentimiento de justicia y de caridad hacia el prójimo que con vena tan rica y conmovedora prodiga la máxima evangélica.

No es del caso detenerse $\alpha$ inquirir los factores humanos que han podido contribujr a esta limitación de resultados: la escasez del clero na. cional, el bajo nivel de cultura de la gran masa aborígen, el cúmulo de supersticiones que en materia religiosa nos dejaron la paganía del Incanato y el fastuoso ritualismo de la Colonia, la diversidad de razas, la desmesurada extensión del medio geográfico, la tendencia agnóstica o librepensadora del enciclopedismo siglo XIX que tan hondo caló en nuestros medios intelectuales, la pugna actual del materialismo por desvirtuar y destruir los valores espirituales, etc., etc. Más útil nos sería anotar puntos concretos que pudieran servir de jalones a una reforma fructuosa de actitudes.

Se registra insistentemente la impresión de que en el púlpito suele ponerse mucho énfasis en los aspectos doctrinarios, sin insistir lo suficiente en el dictado de las usuales normas cristianas de la vida. Se cree que hay maneras de hacer más sugestiva la verdad religiosa. La prédica no es accesible a la mayoría del público. Acaso haya que tratar más a menudo de divulgar con símbolos las abstrucidades del dogma. No siempre la parábola evangélica rezuma en boca del orador su jugo de delicada poesía, que hace diáfana y amable la palabra divina. Falta a veces el fuego de la emoción humana y de la indignación cristiana para fustigar las injus- 
ticias sociales y el tráfico de los mercaderes. Se teme a veces zaherir al poderoso, y se emplea el eufemismo deferente para condenar el abuso autoritario. De allí que sea convicción generalizada la de que la Iglesia es solidaria de los grandes intereses y mantiene una implícita alianza con los Poderes temporales. Para destruir esta convicción, nunca es demasiado elocuente la digna independencia de actitudes en la política eclesiástica.

Pero donde más se ha echado de menos hasta hace poco tiempo la presencia de la Iglesia es en el campo de la acción social, en el teatro mismo de la pugna de clases, en el escritorio de los gerentes, y en el diálogo con elementos sindicales. Ha faltado divulgación de la doctrina de Cristo en la -lase poderosa para inducirla a suavizar su dureza frente a las demandas del trabajo. Conozco el caso de alto hombre de negocios que hace poco decía $\alpha$ un sacerdote: "Siento no haber sabido antes, Padre, esto que usted me explica: No me lo habían enseñado". Ha faltado también contacto humano con los obreros de la ciudad $y$ el campo para acompañarles en sus tugurios $y$ en sus chozas para mostrarles como admiran y respetan esas manos encallecidas que en la obra manual parecen hablar una especie de divino lenguaje, cuyas frases no alcanzan a entender los directorios patronales; para limar las asperezas y aliviar las penurias de su vida diaria; para probarles con los hechos que si el sacerdote sabe consolar una desgracia y elevar preces ante una tumba, sabe también sentir cómo duelen en las entrañas los garfios de la miseria; para hacerles ver que en la hora de la justicia, no se limitan a predicar resignación, sino que saben apoyar con su autoridad moral las reivindicaciones justas $y$ humanas $y$ les muestran el camino de llegar hasta el alma de sus principales con argumentos de verdad que harán inútil la violencia; para demostrarles, en suma, que la Iglesia no está solidarizada con ninguna oligarquía o menudo interés.

Afortunadamente esta labor social del sacerdote se ha iniciado ya y habrá bien pronto de rendir insospechados frutos. $Y$ ha comenzado también a extenderse por nuestros barrios pobres, por las parroquias populares, por los villorrios campesinos la acción del apostolado seglar, en la cual participan fervorosamente miembros de esas mismas capas altas y media de la sociedad hasta las cuales no había llegado antes de ahora en toda su profunda fibra humana el mensaje evangélico.

En este sentido, cabe decir que la orientación de la Iglesia se ha dirigido de preferencia en el Perú a fomentar las obras de caridad, en la cual realizan ejemplar y sacrificada tarea en favor de las clases desvalidas numerosas Congregaciones religiosas de ambos sexos, verdaderos ángeles guardianes de nuestros pobres. Al llamado de la caridad han respondido siempre los sectores acomodados y medios, como solícito y generoso concurso, porque precisamente está dentro de su concepción mental mós arraigada la idea de que la limosna es la única forma en que la caridad tiene traducción. Le ha faltado a la Iglesia poner su acento ante esos sectores en la afirmación de que la mecánica de la caridad es mucho menos simple que eso; que la verdadera caridad no es dádiva, sino deber; que no es mera expresión de compasión o de piedad, sino que ha de ser severo dictado de conciencia que inspire una conducta; y que, en el fondo, la caridad es una forma de justicia, que obliga al empresario cristiano $\alpha$ dar $\alpha$ 
cada uno lo que es suyo y a reconocer al trabajador, en lo espiritual y lo económico, lo que en verdad le es debido como remuneración de su indispensable aporte en la tarea del desenvolvimiento social. Para quienes no aprendan el hábito de esta caridad justa, de esta equidad interior, la limos. na será sólo un aspecto mutilado del problema, un beneficio trunco, el lado generoso de una ecuación frustrada en que se da con una mano lo que se quita con la otra.

Otro de los campos en que ha faltado acción de la Iglesia es el de la educación de las clases populares. Se nota un vacío en materia de escuelas parroquiales nocturnas para adultos, de escuelas libres para niño: de institutos privados de reeducación de la infancia, de locales de cine educativo. Las misiones de la selva, modelo de heroismo y de esfuerzo secular en que los religiosos de varias órdenes hacen oblación dé su salud y de su vida por catequizar al aborigen, no pueden dar a su labor una orientación más proficua y moderna por deficiencia de elementos materiales. Los católicos apenas paran mientes en ellas. En los sectores campesinos de todo el territorio nacional, la acción del cura de aldea no alcanza a llenar sus objetivos. Está prácticamente reducida a la administración de los Sacramentos. La imposibilidad económica o el descuido de una propaganda más intensa da lugur a que otras religiones le disputen a la Iglesia Católica la delantera en la iniciación de prosélitos $\mathrm{Y}$ en la captación de servicios sociales.

Éajo un aspecto objetivo, los hechos que anotamos observando la actitud de las clases en la realidad de nuestro medio son escuetamente enunciados: la creencia de las clases poderosas de que la Iglesia ha de ser un auxiliar suyo para la defensa de las posiciones consagradas dentro de la estructura social tradicional; la tendencia de las capas medias a vivir un tanto lejos de las ordenanzas religiosas, prefiriendo aquellas fórmulas de vida mixta en que se combina amablemente ingredientes de costumbres paganas y superticiones cristianas; y el alejamiento bastante generalizado del obrero respecto de las prácticas de la fe y de las normas de la moral cristiana. En el pueblo sencillo $y$ en el campo es más perceptible el sentimiento religioso, pero se mezcla $\alpha$ la vez con ritos de factura criolla $y$ resabios de superstición.

Las anteriores comprobaciones, y en general el examen de hechos contenido en este trabajo bastan para revelar que los católicos del Perú carecen de conocimiento a fondo de la doctrina de su religión $\mathrm{y}$, sobre todo, no han sabido asumir todavía sus responsabilidades de hombres $\mathrm{y}$ de creyentes trente al fenómeno social que plantea la existencia de las clases. No ha de olvidarse en este punto que la responsabilidad mayor gravita especialmente sobre los estratos cultos, sean altos o medianos, de la sociedad, pues que de ellos debe irradiar hasta el pueblo el resplandor de las virtudes y la eficacia del ejemplo. Las clases dominantes reciben una educación cristiana bastante bien reglamentada en el hogar $y$ en los planteles privados; pero sea porque esa educación es más bien formalista que pro. funda, sea porque el vértigo de la vida social las aleja de las nocione 
aprendidas, lo cierto es que esas clases descuidan con frecuencia sus prácticas religiosas o reducen a sólo ellas el ejercicio de su catolicismo, olvidando otros aspectos no menos esenciales. Cabe preguntarse si los educadores saben presentar en los colegios en su verdadero patetismo el tema vivo y sangrante de las realidades sociales, o lo evaden por satisfacer convencionales prejuicios o para evitar críticas de los propios padres de familia.

En suma: en el esbozo que aquí hacemos del estado del catolicismo en el Perú hay que reconocer graves lagunas, tanto en la acción de la Iglesia como en la conducta de los hombres que profesamos esa religión. Otra ponencia del programa de esta Semana Social señalará, a su tiempo los remedios. 